Historic, Archive Document

Do not assume content reflects current scientific knowledge, policies, or practices. 



\section{Green's Nursery Co.}

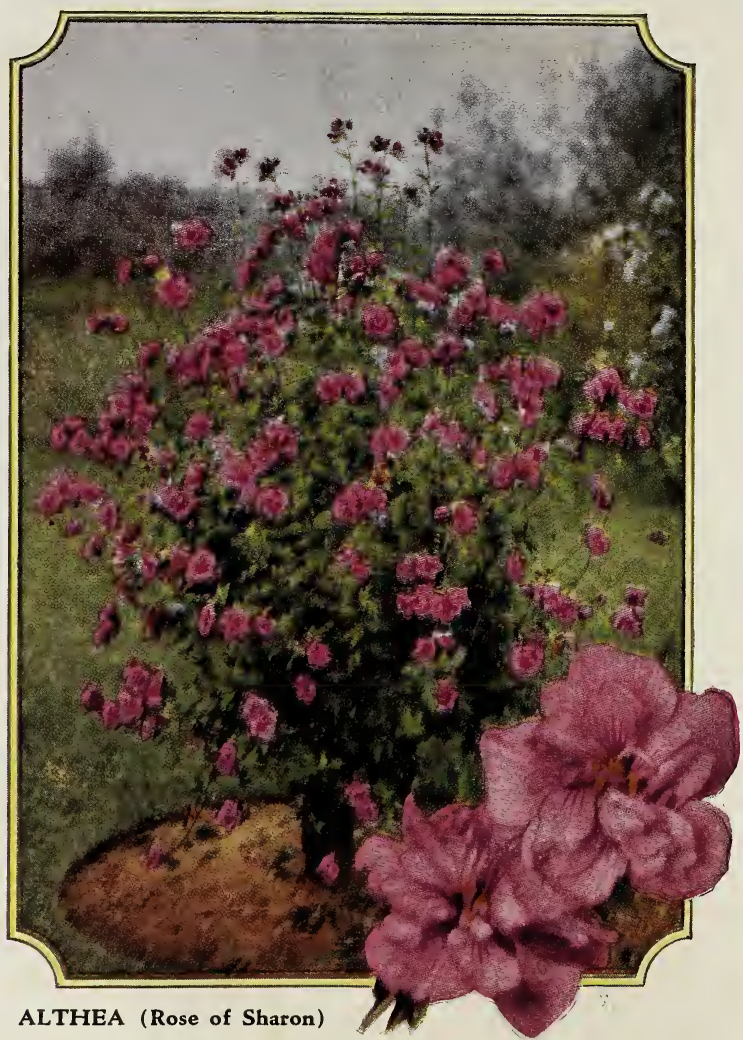

TERMS

With our very low prices we can operate only on a cash with order basis. However, stock will be shipped C. O. D. if one-fourth of purchase price accompanies order.

\section{LIBERAL DISCOUNT FOR EARLY ORDERS}

We allow $10 \%$ CASH DISCOUNT on all orders received with cash before March 20. 5\% CASH DISCOUNT between March 20 and April 15. No discount on C. O. D. orders. Unless special date of shipment is requested, we will ship so as to reach you at the best time for planting in your section.

\section{SATISFACTION GUARANTEED}

We guarantee every Tree, Plant or Vine sold by us to be strong, vigorous and healthy, and to deliver them to you in good condition. If for any reason you are not absolutely satisfied with your stock when it is received, advise us at once, and we will gladly replace the items or refund your money.

Green's Trees are True-to-Name. No human caution could be more exacting than ours. If any trees prove untrue to name, upon proper proof, we will replace or refund the purchase price. Obviously, we cannot assume further responsibility than this. 


\section{Rochester, N. Y.}

\section{Green's Shrubs}

Almond, Pink Flowering-Grows 6-8 ft. Pink flowers in early spring. $2.3 \mathrm{ft}$., $75 \mathrm{c}$ each.

Almond, White Flowering-Grows $6.8 \mathrm{ft}$. White flowers early in spring. $2.3 \mathrm{ft}$., $75 \mathrm{c}$ each.

Althea (Rose of Sharon)-Grows 8-10 ft. Double, rose-shaped flowers in pink, purple, red, white, rose with darker center. Order by color. $2.3 \mathrm{ft}$., $50 \mathrm{c}$ each.

Barberry, Red-Leaved Japanese Dwarf-Reddish bronze foliage, turning to bright red during summer. Plant in sun. $1-11 / 2 \mathrm{ft}$., $\$ 1.00$ each; $\$ 8.00$ per 10 .

Beauty Bush-Grows $6-8 \mathrm{ft}$. A new variety, producing fountains of pink flowers. $11 / 2-2 \mathrm{ft}$., $\$ 1.25$ each.

Butterfly Bush-Grows $3.4 \mathrm{ft}$. Long spikes of lavender flowers. 2.3 ft., $50 \mathrm{c}$ each.

Bush Honeysuckle, Pink Tartarian-Grows $6.8 \mathrm{ft}$. Pink flowers in May. 2-3 ft., $50 \mathrm{c}$ each; $3.4 \mathrm{ft}$., $75 \mathrm{c}$ each.

Bush Honeysuckle, White Tartarian-Grows 6-8 ft. White flowers in May. 2.3 ft., $50 \mathrm{c}$ each; $3.4 \mathrm{ft}$., $75 \mathrm{c}$ each.

Deutzia, Double Rose (Crenata Plena)-Grows 6-8 ft. White flow ers, tinged with rose in June. $2-3 \mathrm{ft}$., $50 \mathrm{c}$ each; $3-4 \mathrm{ft}$., $75 \mathrm{c}$ each.

Deutzia, Pride of Rochester-Grows 6-8 ft. Pinkish white flowers in May. 2-3 ft., $50 \mathrm{c}$ each; $3.4 \mathrm{ft}$., $75 \mathrm{c}$ each

Deutzia, Slender (Gracilis)-Grows $3.4 \mathrm{ft}$. White flowers in May. $11 / 2-2 \mathrm{ft}$., $75 \mathrm{c}$ each.

Deutzia, Snowflake (Candidissima)-Grows 6-8 ft. White flowers in June. $2.3 \mathrm{ft}$., $50 \mathrm{c}$ each.

Golden Bell, Border (Forsythia)-Grows 8-10 ft. Bright yellow flowers in April. 2.3 ft., $50 \mathrm{c}$ each; $3.4 \mathrm{ft} ., 75 \mathrm{c}$ each.

Golden Bell, Weeping (Forsythia)-Grows $6.8 \mathrm{ft}$. Bright yellow flowers in April. 2-3 ft.. $75 \mathrm{c}$ each.

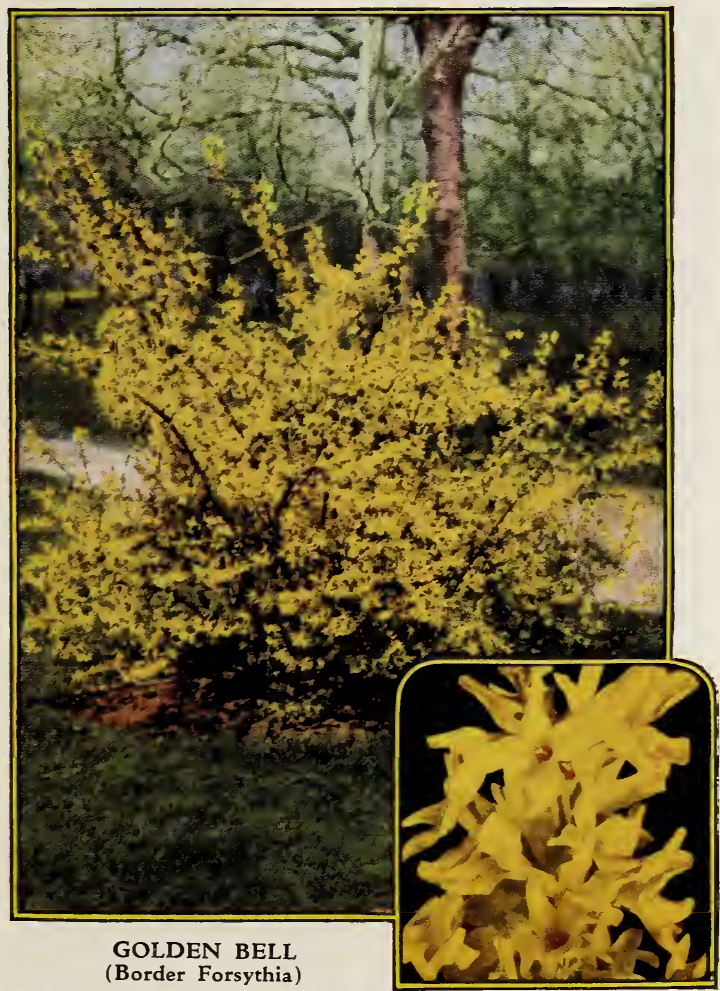

(Border Forsythia)

You Save Agents' Commissions When You Buy of Us 
Golden Elder-Grows 10-12 ft. Yellow leaves. White flowers in May. 2.3 ft., $50 \mathrm{c}$ each; $3.4 \mathrm{ft}$., $75 \mathrm{c}$ each.

High Bush Cranberry-Grows 8.10 ft. Elderberry-like blossoms of white. Scarlet berries in fall. $2.3 \mathrm{ft} ., 75 \mathrm{c}$ each.

Hydrangea, Arborescens Grandiflora (Hills of Snow)-Grows 3-4 $\mathrm{ft}$. Ball-shaped white flowers in July. $2-3 \mathrm{ft}$., $75 \mathrm{c}$ each.

Hydrangea, Paniculata Grandiflora (Bush Form)-Grows 6.7 ft. White, globe-shaped flowers, tinged with pink in Aug. $11 / 2 \cdot 2$ $\mathrm{ft} ., 40 \mathrm{c}$ each; $2-3 \mathrm{ft}$., $50 \mathrm{c}$ each; $3.4 \mathrm{ft}$., $75 \mathrm{c}$ each.

Hydrangea, Paniculata Grandiflora (Tree Form)-Grows 8-10 ft. Miniature trees. Bloom same as bush form. $2-3 \mathrm{ft}$., $\$ 1.00$ each.

Indian Currant (Coral Berry)-Grows $3.4 \mathrm{ft}$. Rose-colored flowers in June. Red berries in fall. $2.3 \mathrm{ft}$., $50 \mathrm{c}$ each.

Japan Quince-Grows 6.8 ft. Scarlet flowers in May. $11 / 2.2 \mathrm{ft}$., $60 \mathrm{c}$ each.

Kerria Japonica (Double)-Grows 6-8 ft. Light green branches. Yellow flowers during summer. $2.3 \mathrm{ft}$, $\$ 1.00$ each.

Mock Orange, Golden-Grows $3.4 \mathrm{ft}$. Bright yellow foliage, white flowers in May or June. $11 / 2-2 \mathrm{ft}$., $75 \mathrm{c}$ each.

Mock Orange, Large Flowered-Grows 8.10 ft. Large, spreading branches. Creamy white flowers. May or June. 2-3 ft., $50 \mathrm{c}$ each; $3.4 \mathrm{ft}$., $75 \mathrm{c}$ each.

Mock Orange, Virginal-Grows 6-8 ft. New variety. Extra large, double white flowers from June until frost. $2.3 \mathrm{ft}$., $75 \mathrm{c}$ each.

Pearl Bush-Grows 6-8 ft. Buds, like pearls strung on slender threads, opening pure white. $2.3 \mathrm{ft}$., $75 \mathrm{c}$ each.

Regel's Privet-Grows 6-8 ft. Drooping branches. White flowers. Fall foliage, red. $2.3 \mathrm{ft}$., $50 \mathrm{c}$ each.

Snowberry-Grows $3.5 \mathrm{ft}$. Small rose-colored flowers in June. Large white berries in fall. $2.3 \mathrm{ft}$., $50 \mathrm{c}$ each.

Snowball, Japanese-Grows 6-8 ft. Purple foliage. Balls of white flowers in June. $2.3 \mathrm{ft}$., $\$ 1.00$ each.

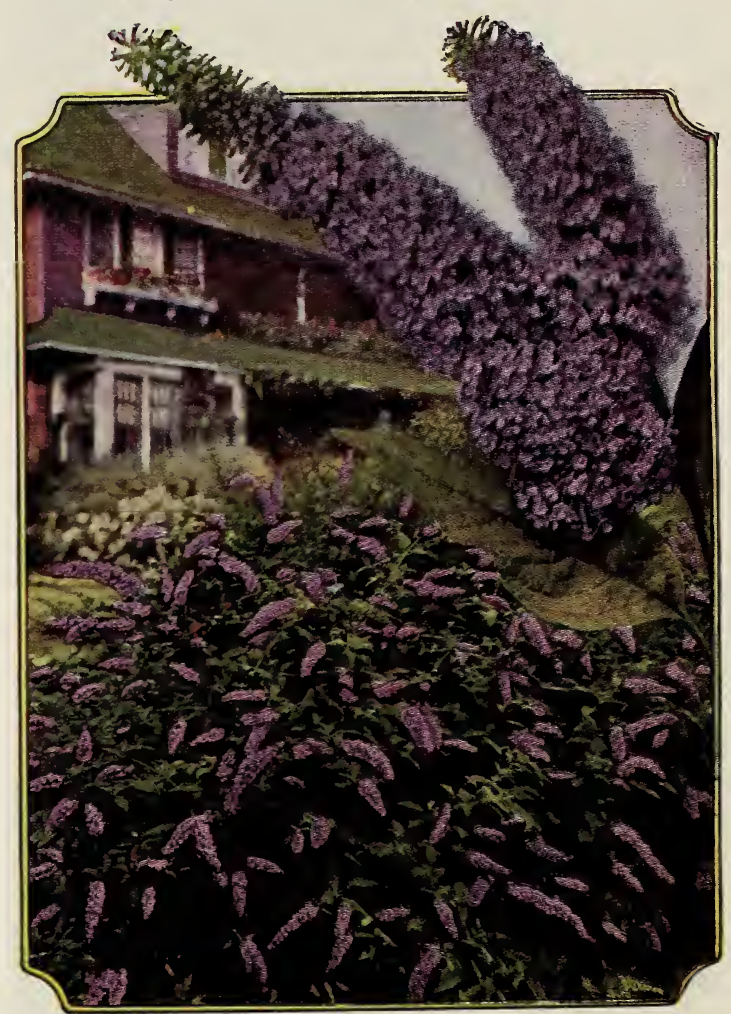

BUTTERFLY BUSH-Sometimes Called Summer Lilac

Shrubs Not Over 2 to 3 Feet Can Be Sent Parcel Post5c Extra for Postage 
Snowball, Old-Fashioned (Common)-Grows 8.10 ft. Favorite shrub, with balls of white flowers in May. 2.3 ft., 75c each.

Spiraea, Anthony Waterer-Grows 2- $3 \mathrm{ft}$. Striking purple-red flow-

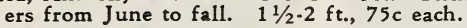

Spiraea, Billard's (Billardi)-Grows $4.6 \mathrm{ft}$. Dense spikes of rosepink flowers in July. $2.3 \mathrm{ft}$., $50 \mathrm{c}$ each; $3.4 \mathrm{ft}$., $75 \mathrm{c}$ each.

Spiraea, Froebel's (Froebeli)-Grows $3.5 \mathrm{ft}$. The Improved Anthony Waterer. Taller, with larger flowers. $2-3 \mathrm{ft}$., $50 \mathrm{c}$ each.

Spiraea, Golden-Grows 8.10 ft. Golden foliage, with masses of snow white flowers in June. $2.3 \mathrm{ft}$., $50 \mathrm{c}$ each; $3.4 \mathrm{ft}$., $75 \mathrm{c}$ each.

Spiraea, Van Houttei (Bridal Wreath)-Grows 6.8 ft. Graceful, drooping branches covered with snow white flowers in May and June. $2.3 \mathrm{ft}$., $50 \mathrm{c}$ each; $3.4 \mathrm{ft}$., $75 \mathrm{c}$ each.

Weigela, Candida-Grows $4.5 \mathrm{ft}$. Ivory-white flowers on graceful, arching branches in June. $2.3 \mathrm{ft}$., $50 \mathrm{c}$ each.

Weigela, Eva Rathke-Grows $3.5 \mathrm{ft}$. Fine dark red. Dwarf habit. Blooms from June to fall. $2.3 \mathrm{ft}$., $\$ 1.00$ each.

Weigela, Pink-Grows 6-8 $\mathrm{ft}$. Deep pink flowers in great profusion in June. 2-3 ft., $50 \mathrm{c}$ each.

\section{FRENCH LILACS}

Selection of these varieties was made from the famous Highland Park collection here in Rochester. All grow 6.8 ft. Prices of all French Lilacs, 2-3 ft., $\$ 1.00$ each.

Charles Joly-Large, double flowers of dark reddish purple.

Charles X-Large trusses of single flowers, light lavender.

Ludwig Spaeth-Large, single flowers, dark purplish blue.

Madam Casimer Perier-Double white flowers. Dwarf grower.

Marie Legraye-Immense, single white flowers. Dwarf grower.

President Grevy-Immense, double pale wisteria violet flowers.

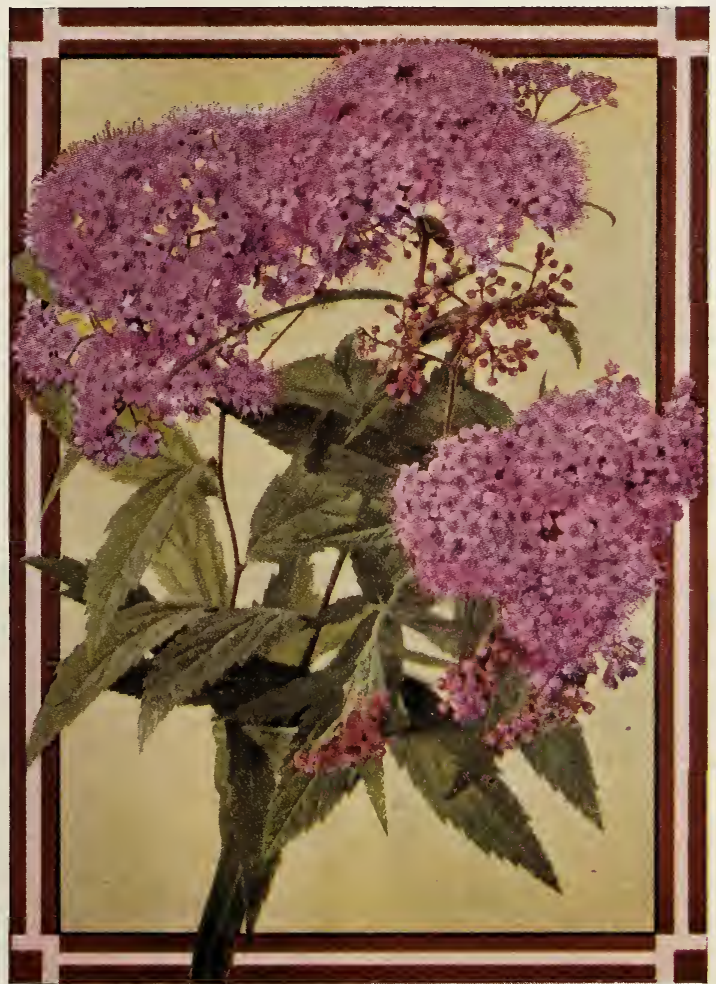

BLOSSOMS OF ANTHONY WATERER SPIRAEA

Our Shrubs Will Bloom Same Season Planted 


\section{Green's Nursery Co.}

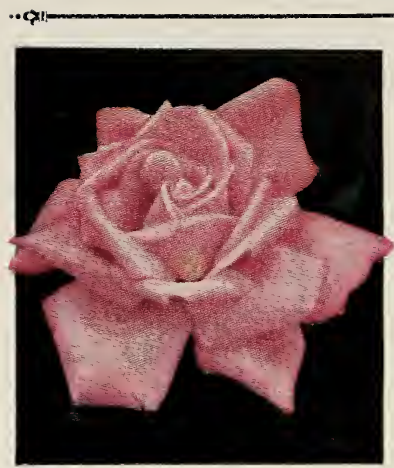

COLUMBIA

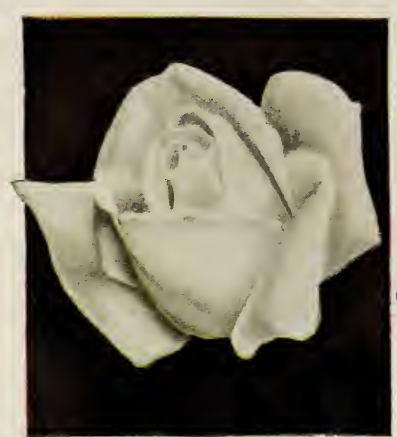

KAISERIN AUGUSTA
VICTORIA

\section{ROSES}

EVERBLOOMING ROSES-Hybrid Teas CALLED MONTHLY ROSES BECAUSE THEY BLOOM FROM JUNE UNTIL FROST.

Prices of Hybrid Tea Roses-All Varieties Except Souvenir de Claudius Pernet: Strong, Two-Year Bushes, 85c each; 10 for $\$ 7.50$.

Columbia-Long-stemmed, with rose-pink buds.

Duchess of Wellington-Semi-double, saffron-yellow buds.

Edward Mawley-Deep blackish-crimson.

Gruss an Teplitz-Freest of bloomers. Dark rich crimson.

Kaiserin Augusta Victoria--Ivory-white blooms.

Los Angeles-Pink, overlaid with deep yellow at base.

Luxemburg-Large. Deep yellow.

Madam Butterfly-Blending from pink to coppery gold.

Mrs. Aaron Ward-Burnt orange, fading to yellow at tips.

Madam Edouard Herriot-Sparkling buds of coral-red and orange.

Ophelia-Delicate salmon, flesh-shaded with rose.

Radiance-Lovely, light silvery pink.

Red Radiance-Deep red, with intense fragrance.

Souvenir de Claudius Pernet---Bright sunflower-yellow. $95 \mathrm{c}$ each; 10 for $\$ 8.50$.

\section{MISCELLANEOUS ROSES}

Crimson Baby Rambler-A dwarf bush, covered with crimson flowers. $85 \mathrm{c}$ each; 10 for $\$ 7.50$.

Multiflora (Live Forever)--Ideal for rose hedge. Free bloomer. Pinkish white. Strong, two-year bushes, $50 \mathrm{c}$ each; 10 for $\$ 4.00$.

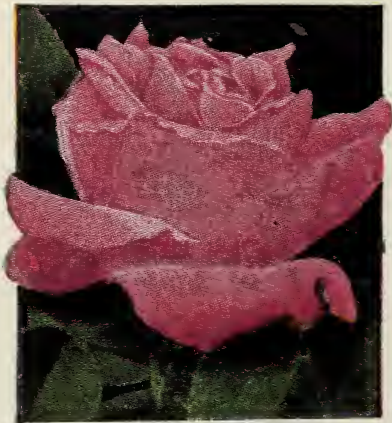

RADIANCE (Pink)

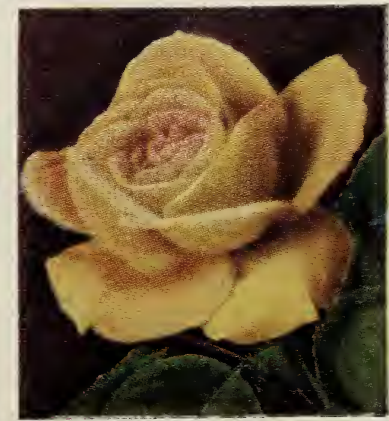

SOUVENIR DE CLAUDIUS PERNET

Roses by Parcel Post, Postpaid-5c per Bush Extra 


\section{Rochester, N.Y.}

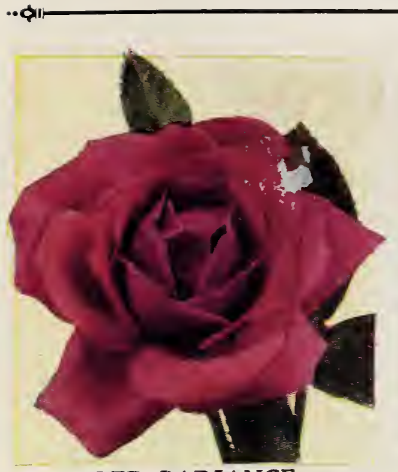

RED RADIANCE

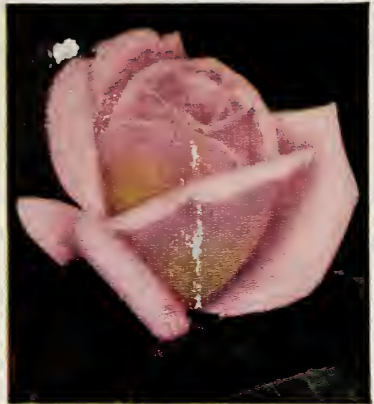

MME. BUTTERFLY

HYBRID PERPETUAL ROSES

FREE BLOOMERS IN JUNE AND SOMETIMES SPARINGLY UNTIL FALL.

Prices of Strong, Two-Year-Old Bushes: 80c each; 10 for $\$ 7.00$.

Frau Karl Druschki-Pure snow-white.

General Jacqueminot-Old favorite. Brilliant scarlet-crimson.

Madam Plantier-Fragrant, large white flowers.

Magna Charta-Large flowers of rose-carmine.

Paul Neyron-Largest rose in existence. Creamy pink.

\section{HARDY CLIMBING ROSES}

THE CLIMBERS OR RAMBLERS AFFORD A BURST OF BLOOM UPON TRELLISES OR HEDGES.

Prices of Strong, Two-Year-Old Bushes: 60c each;

$$
10 \text { for } \$ 5,00 \text {. }
$$

Climbing American Beauty-One of the best. Lovely American Beauty pink.

Crimson Rambler-Unusually vigorous. Profusion of double red blossoms.

Dorothy Perkins-Full, double, shell-pink flowers in large clusters. Dr. Van Fleet-Double, light shell-pink to silver flesh.

Excelsa-Red Dorothy Perkins. Crimson color.

Hiawatha-Single crimson flowers, with white base.

Paul's Scarlet Climber-Brilliant scarlet. Maintains blooms and petals until fall.

Silver Moon-Large, semi-double, pure white.

Tausendschon (Thousand Beauties)-Varies in several shades of pink.

Veilchenblau (Blue Rambler)-Double flowers of light lilac, fading to purple-blue

White Dorothy-The white Dorothy Perkins.

Yellow Rambler-Yellow buds which fade to creamy white.

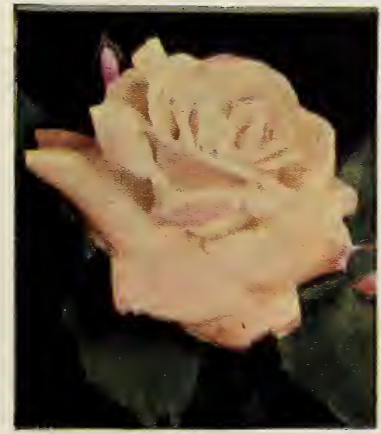

OPHELIA

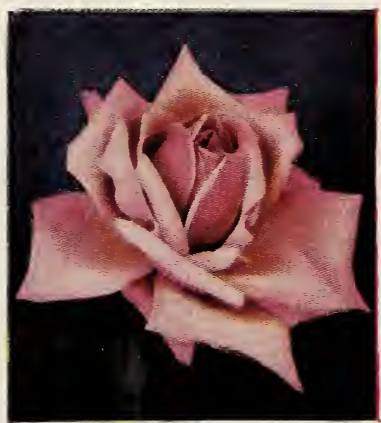

LOS ANGELES

Our Roses Will Bloom Same Season Planted 


\section{Green's Nursery Co.}
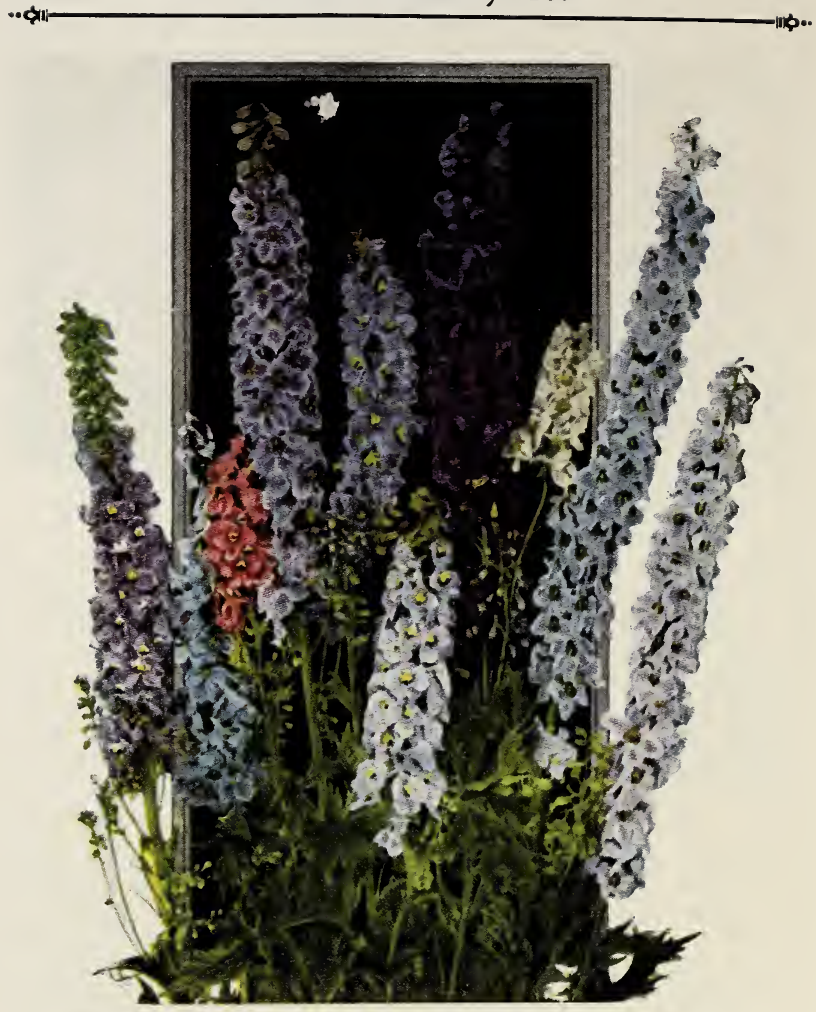

WATKINS AND SIMPSON'S HYBRID DELPHINIUMS

\section{Perennials}

Prices of All Perennials-Unless Otherwise NotedStrong, Field-Grown Plants, 30c each; $\$ 2.50$ per 10, postpaid.

Anchusa Dropmore (Heavenly Blue Flower)-Grows $4-5 \mathrm{ft}$. Tall spikes of blue flowers from June to Sept.

Baby's Breath (Gypsophila) - Grows 2.3 ft. Delicate white flowers, June and July.

Blanket Flower (Gaillardia)-Grows 12.18 in. Yellow and orange flowers, June to Nov.

Blazing Star (Liatris) - Grows $4.5 \mathrm{ft}$. Narrow spikes, purple flowers. July and Aug.

Bleeding Heart (D. Spectabilis)-Grows 2-3 ft. Pink, heart-shaped flowers. April to June.

Canterbury Bell (Campanula)-Grows $2.3 \mathrm{ft}$. Order by color: White, Rose, Blue. June and July.

Carnations (Hardy Double) - Grows $1 \mathrm{ft}$. We offer fine strain of mixed colors. June and July.

Chrysanthemums (Hardy Double)-Grows 3-4 ft. Order by color: Pink, Red, White and Yellow. Oct and Nov.

Columbine (Aquilegia, Long Spurred)-Grows 2-3 ft. Mixed colors, blue, rose, white, yellow, pink. May to June.

Coreopsis (Tickseed) - Grows $2 \mathrm{ft}$. Golden yellow flowers, June to fall.

Day Lily, Yellow-Grows $3 \mathrm{ft}$. Large, clear amber-yellow flowers.

Day Lily, Orange-Grows $3 \mathrm{ft}$. Large flowers of beautiful orange. June and July.

Delphinium, Belladonna (Hardy Larkspur)-Grows $4.5 \mathrm{ft}$. Large spikes of delicate blue flowers. June to Oct.

Delphinium, Bellamosum (Hardy Larkspur) -Grows 4-5 ft. Large spikes of dark blue flowers. June to Oct.

We Ship All Perennials Separately, by Parcel Post 
Delphinium, Watkins and Simpson's Hybrid (Hardy Larkspur) Grows 4-5 ft. New imported English strain. Huge flowers varying in hues of light blue to deep purple. June to Oct. varying in hues of light blue to deep purple. June to Oct.

Foxglove (Digitalis) - Grows 4-5 ft. Bell-shaped flowers of white, pink, rose mixed. July and Aug.

German Iris (Fleur-de-Lis)-Orchid-like flowers in May and June, in the following colors. Order by color: White, Rose-pink, Light Violet, Purple, Lavender-rose, Light Blue, Clear Blue, Orchid Color, Yellow Mahogany, White with Blue Edge.

Hardy Primrose (Primula)-Grows 6-9 in. Bright yellow, with gold center. April and May.

Hollyhocks (Althea Rosea)-Stately stalks with rose-like flowers in July and Aug. We offer a range of colors. Order by color: Rose, Red, White, Salmon, Newport-pink, Yellow-all double flowers.

Lupines-Grows 3-4 ft. Spikes of pea-shaped flowers. Mixed colors, blue, rose, white. June to Aug.

Mallow Marvels (Hibiscus)-Grows $4.5 \mathrm{ft}$. Giant flowers, white, rose, blue. Order by color. July to Sept.

Monarda (Beebalm) - Grows $3 \mathrm{ft}$. Large, scarlet flowers, June to Aug.

Moss Pink (Phlox Subulata)-Grows 6-8 in. Fine for rockery and borders. Pink flowers, April and May.

Oriental Poppy-Grows 2.3 ft. Bright crimson flowers, with black centers. May to July.

Painted Daisy (Pyrethrum)-Grows 2-3 ft. Large daisies in mixed colors, white, pink, rose, crimson. July-Sept.

Red Hot Poker (Tritoma)-Grows 3-4 ft. Spikes of orange-scarlet flowers. Aug. to Oct.

Shasta Daisy-Grows $2 \mathrm{ft}$. Improved strain. Large, white blossoms. June and July.

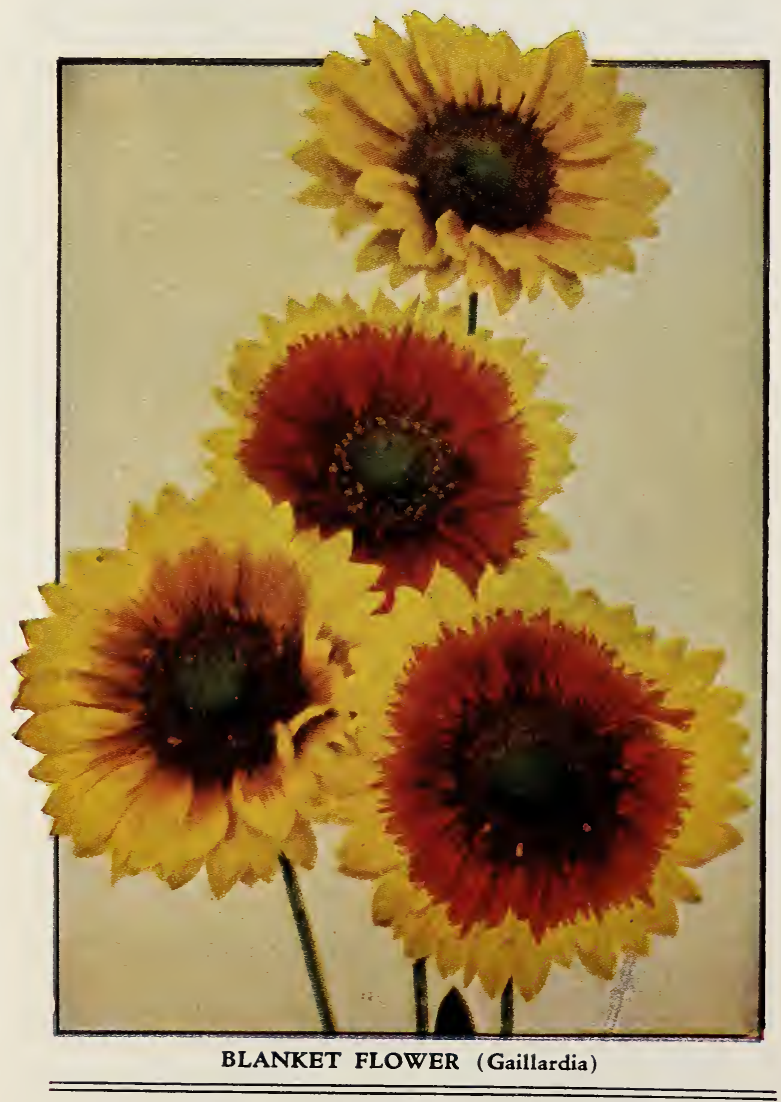

Prices on Perennials Include Postage 
Sweet William-Great masses of extremely rich colored flowers in May and June. Grows $2 \mathrm{ft}$. We offer the following varieties: Newport Pink-Salmon rose-pink.

Scarlet Beauty-Rich deep scarlet.

Mixed Colors-Red, white and rose mixed.

Yucca, Filamentosa-Grows 4.5 ft. Sword-like, evergreen foliage. Creamy-white flowers.

Yucca, Variegated Leaved-Grows $4.5 \mathrm{ft}$. Same as above except leaves have a dark bronze stripe, with yellow outer edge. $75 \mathrm{c}$ each; $\$ 7.00$ per 10 , postpaid.

\section{PAEONIES}

\section{(SELECTED VARIETIES)}

Prices-Unless Otherwise Noted-Strong Roots, 3 to 5 Eyes, 60c each; $\$ 5.00$ per 10 , Postpaid.

Duchess De Nemours-Early. Outer petals pure white, center lemon-yellow. Fragrant.

Duchess De Orleans-Outer petals pink, center cream color. Fragrant. Free bloomer. Mid-season.

Edulis Superba-Clear pink. Very fragrant. One of the earliest to bloom. 75c each; $\$ 7.00$ per 10.

Felix Crousse-Very brilliant red. Large. Fragrant.' Mid-season. $\$ 1.00$ each; $\$ 9.00$ per 10 .

Floral Treasure-Pale lilac-rose. Very large and fragrant. Midseason.

Madam De Verneville-Pure white, center blush, carmine flecks. Fragrant. Mid-season.

Marechal Valliant-Dark mauve-pink. Very large; rose type. Late.

Modeste Guerin-A bright, deep pinkish-red. Very fragrant. An extra fine variety. Mid-season.

\section{PHLOX}

\section{(SELECTED VARIETIES)}

Prices-Strong, Field-Grown Plants, 30c each; $\$ 2.50$ per 10 , postpaid. General Von Huetz-Bright salmon-red, white center.

Jules Sandeau-Pure pink. Very large heads.

Mrs. Millie Van Hoboken-Soft pink. A new variety.

Mme. Benzanon-Brick-red.

Mrs. Jenkins-Pure white. "Very early.

Purity-White.

Richard Wallace-White, with carmine eye.

Rynstrom-Lively rose-pink. Large.

Thor-Rich salmon-pink, with deep crimson eye.

\section{Nuts}

Black Walnut-A large tree of majestic form and beautiful foliage. Bears large, round nuts of excellent quality. Prices: 6 to 8 $\mathrm{ft}$., $\$ 1.00$ each; $\$ 9.50$ per 10.5 to $6 \mathrm{ft}$., $85 \mathrm{c}$ each; $\$ 8.00$ per 10.4 to $5 \mathrm{ft}$., $75 \mathrm{c}$ each; $\$ 7.00$ per 10 . 3 to $4 \mathrm{ft}$., $60 \mathrm{c}$ each; $\$ 5.50$ per 10. By Parcel Post, 2 to $3 \mathrm{ft}$., $55 \mathrm{c}$ each; $\$ 5.00$ per 10 , postpaid.

Butternut-Valued for its tropical appearance and beautiful wood. Produces large crops of oblong, nutritious nuts. Prices: 6 to $8 \mathrm{ft}$., $\$ 1.25$ each; $\$ 12.00$ per 10 . 5 to $6 \mathrm{ft}$., $\$ 1.00$ each; $\$ 9.50$ per 10 . 4 to $5 \mathrm{ft} ., 85 \mathrm{c}$ each; $\$ 8.00$ per 10 . 3 to 4 ft., 70c each; $\$ 6.50$ per 10 . By Parcel Post, 2 to $3 \mathrm{ft}$., $60 \mathrm{c}$ each; $\$ 5.50$ per 10 , postpaid.

English Filbert (Hazelnut) $-A$ low-growing, bushy tree, producing abundant crops of roundish, tender nuts of fine flavor. Prices: 3 to $4 \mathrm{ft}$., $70 \mathrm{c}$ each; $\$ 6.50$ per 10 . 2 to $3 \mathrm{ft}$., $60 \mathrm{c}$ each; $\$ 5.50$ per 10 . By Parcel Post, 18 to 24 in., $55 \mathrm{c}$ each, postpaid.

English Walnut-A fine, lofty-growing tree, with handsome, spread. ing head. Produces large crops of nuts, which are apt to vary in size and quality. Prices: 3 to $4 \mathrm{ft}$., $\$ 1.25$ each; $\$ 11.50$ per 10 . 2 to $3 \mathrm{ft}$., $\$ 1.00$ each; $\$ 9.00$ per 10 . By Parcel Post, 18 to 24 in., $90 \mathrm{c}$ each; $\$ 8.50$ per 10 , postpaid.

Japan Walnut (Sieboldi) - This is a very hardy, handsome, rapidgrowing tree, with large leaves. Nuts resemble butternuts, but smaller, smooth and thinner shell. Prices: 4 to $5 \mathrm{ft}$., $\$ 1.25$ each; $\$ 11.50$ per 10 . 3 to $4 \mathrm{ft}$., $\$ 1.00$ each; $\$ 9.00$ per 10 By Parcel Post, 2 to $3 \mathrm{ft}$., $90 \mathrm{c}$ each; $\$ 8.50$ per 10 .

\section{Mulberries}

New American-The best of the edible mulberries. Large, black, delicious, sweet fruit from middle of June to Sept. 5 to 6 ft., $\$ 1.00$ each.

Our Perennials are All Strong, Field-Grown Plants 
Rochester, N. Y.

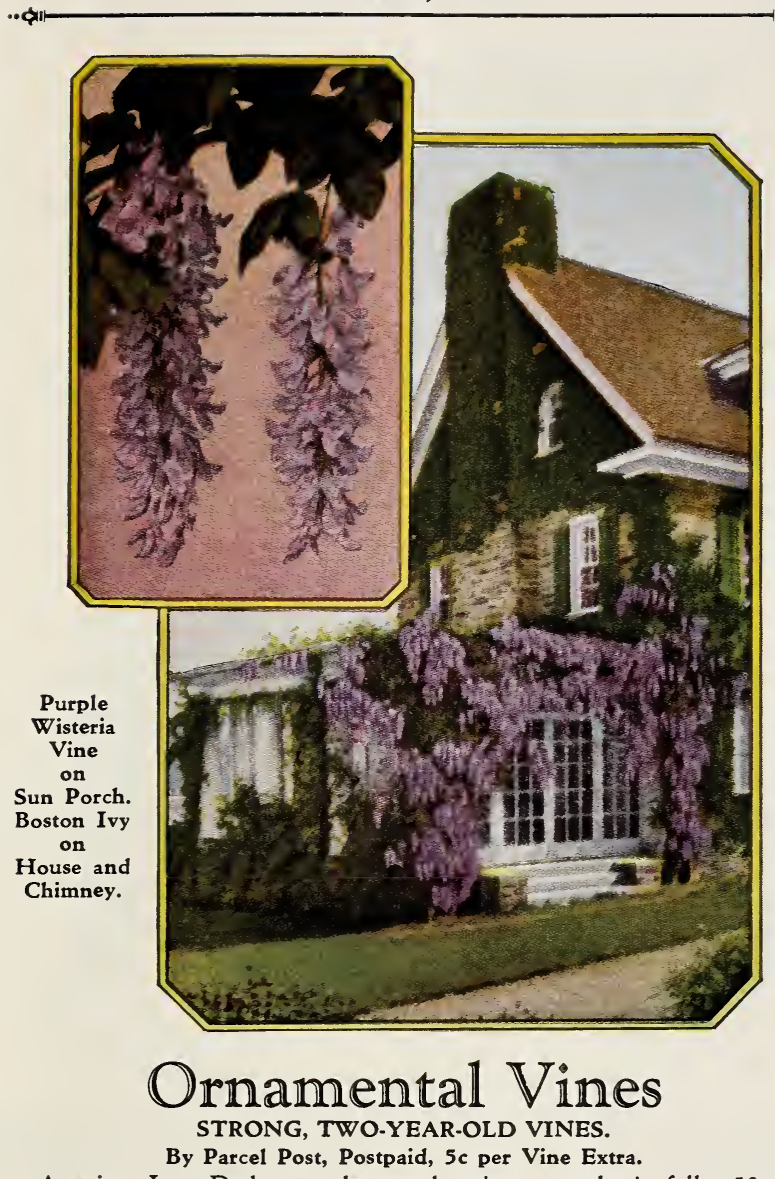

American Ivy-Dark green leaves, changing to scarlet in fall. $50 \mathrm{c}$ each; $\$ 4.50$ per 10 .

Boston Ivy $-A$ rapid grower that clings to brick or stone walls. $75 \mathrm{c}$ each; $\$ 7.00$ per 10 .

Bittersweet-Fine green foliage, with bright red berries in fall. $50 \mathrm{c}$ each; $\$ 4.50$ per 10 .

Clematis Jackmanni-Large purple flowers in July until frost. $85 \mathrm{c}$ each; $\$ 8.00$ per 10 .

Clematis Paniculata-Star-shaped white flowers in September. 50c each; $\$ 4.50$ per 10 .

Dutchman's Pipe-Rapid grower. Dense foliage. $\$ 1.25$ each; $\$ 10.00$ per 10 .

Hall's Japan Honeysuckle-Most popular of climbing vines. White flowers. 50c each; $\$ 4.50$ per 10.

Trumpet Vine-An old favorite. Orange-scarlet flowers. $50 \mathrm{c} \mathrm{each}$; $\$ 4.50$ per 10 .

Purple Wisteria-Clusters of light purple flowers in May. $75 \mathrm{c}$ each; $\$ 7.00$ per 10 .

White Wisteria-Clusters of white flowers in May. 75c each; $\$ 7.00$ per 10 .

* GREEN'S LANDSCAPE SERVICE *

We will be pleased to furnish you complete planting plans for your home grounds, telling you just what to plant and where to plant it. Our charge for these plans is only $\$ 5.00$. If your order amounts to $\$ 50.00$ or more, the $\$ 5.00$ will be credited on your order. If interested, write for our complete catalog giving further details.

It's Not a Home Until It's Planted 


\section{Evergreens}

WILL ADD BEAUTY AND VALUE TO YOUR HOME. ALL TREES BALLED AND BURLAPPED.

NO EXTRA CHARGE.

American Arborvitae A beautiful, pyramidal-shaped tree, with green, spray-like foliage.

\section{Prices of American Arborvitae}

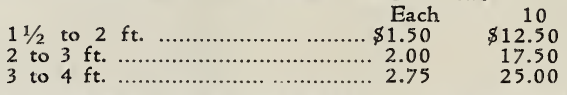

Globe Arborvitae-Dwarf and ball-shaped. 15-18 in., $\$ 2.50$ each.

Pyramidal Arborvitae-An extremely compact, pyramidal-shaped variety, with dark green foliage. $2.3 \mathrm{ft}$., $\$ 4.00$ each; $3.4 \mathrm{ft}$., $\$ 5.00$ each.

Siberian Arborvitae-Semi-dwarf, broad at base, tapering to a point. 15.18 in., $\$ 2.00 \mathrm{each} ; 11 / 2.2 \mathrm{ft}$., $\$ 3.00 \mathrm{each}$.

Tom Thumb Arborvitae-Dwarf-forming pyramid. 12-15 in., $\$ 2.50$ each.

Colorado Juniper-Pyramidal-shaped. Bluish green color. 11/2-2 $\mathrm{ft}$., $\$ 3.00$ each; $2.3 \mathrm{ft}$., $\$ 4.00$ each; $3.4 \mathrm{ft}$., $\$ 5.00$ each.

Pfitzer's Juniper-Low spreading type. Blue green color. 12-15 in., $\$ 3.00$ each; 18.24 in., $\$ 4.00$ each.

Dwarf Mugho Pine-Semi-dwarf, globe-shaped. Dark green foliage. $12-18$ in., $\$ 4.00$ each; $18-24$ in., $\$ 5.00$ each.

Black Hill Spruce-Symmetrical. Dark green color. $18-24$ in., $\$ 3.00$ each; $2-3$ ft., $\$ 4.00$ each.

Colorado Blue Spruce-Symmetrical. Deep blue color. 18.24 in., $\$ 7.50$ each; $2.3 \mathrm{ft}$., $\$ 10.00$ each.

Colorado Green Spruce-Symmetrical. Light green color. 18-24 in., $\$ 3.00$ each; $2-3 \mathrm{ft}$., $\$ 4.00$ each; $3-4 \mathrm{ft}$., $\$ 5.00$ each.

Norway Spruce-The time-honored Christmas tree. Dark green.

$$
\begin{aligned}
& \text { Prices of Norway Spruce }
\end{aligned}
$$

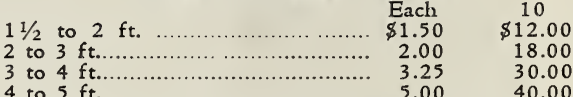

When through with this catalog please lend it to a friend

When through with this catalog please lend it to a friend or neighbor. We will appreciate it, and your friend or neighbor may appreciate it, too. Thank you.

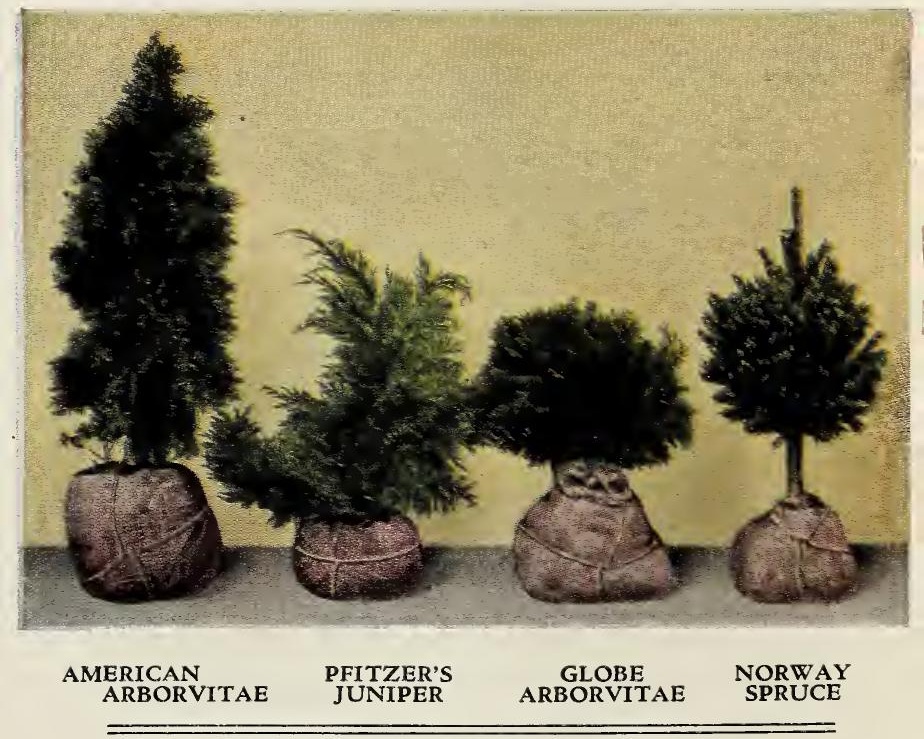

Evergreens Cannot Be Sent Parcel Post 


\section{Rochester, N.Y.}

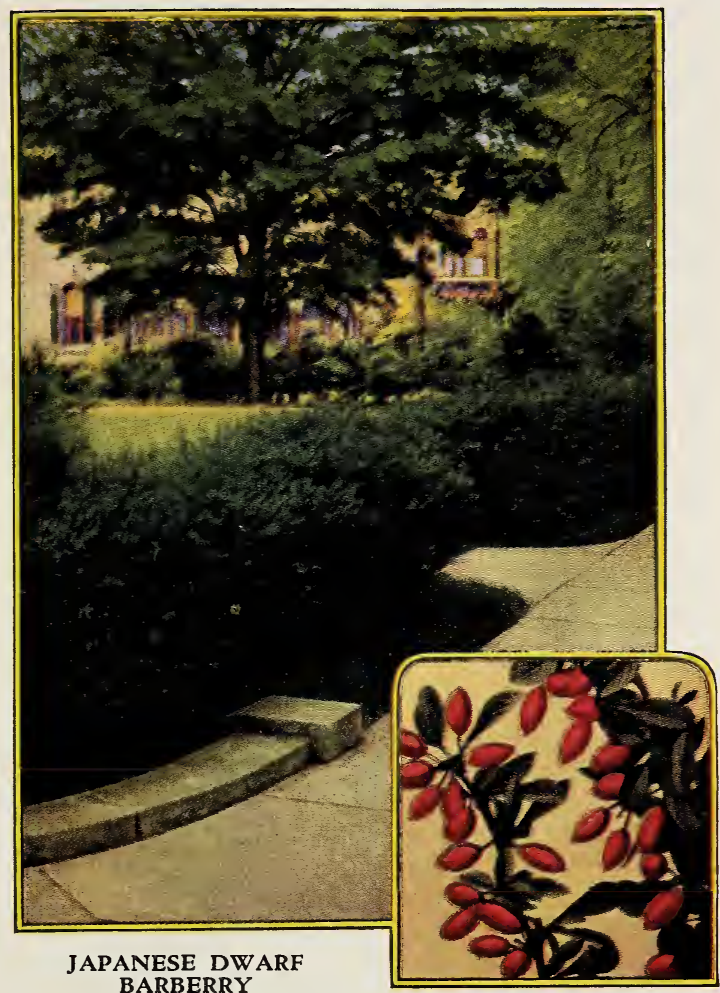

\section{Hedges}

BEAUTIFY AS THEY SERVE

California Privet-An almost evergreen shrub of dense, shapely habit, and fine dark green foliage.

\section{Prices}

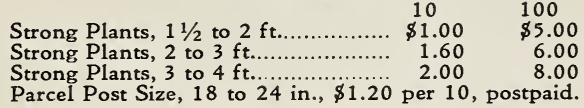

Ibolium Privet-Similar in appearance to California Privet. Recommended for the Northern States.

\section{Prices}

Strong Plants, $11 / 2$ to $2 \mathrm{ft} \$ 100$

Strong Plants, $11 / 2$ to 2 ft........... $\$ 2.00 \quad \$ 12.00$

Parcel Post Size, 18 to 24 in., $\$ 2.75$ per 10 , postpaid.

Japanese Dwarf Barberry-A very dwarf shrub, with fine dark leaves, turning to bright red in fall.

\section{Prices}

Strong Plants, 1 to $11 / 2 \mathrm{ft} \ldots \ldots . \quad \begin{array}{llll}\$ 0.25 & \$ 2.00 & \$ 15.00\end{array}$

Strong Plants, $11 / 2$ to $2 \mathrm{ft}$..... $.30 \quad 2.50 \quad 18.00$

Strong Plants, 2 to $3 \mathrm{ft}$......... $.40 \quad 3.00 \quad 22.00$ Parcel Post Size, 12 to 18 in., $30 \mathrm{c}$ each; $\$ 2.50$ per 10 , postpaid.

RATES-Less than ten at each rates. Ten to fifty at ten rates. Fifty or more at hundred rates. 


\section{Ornamental Trees}

Ash, Am. Mountain-Grows 20-30 ft. Dark green foliage. Bright red berries. 4-5 ft., $\$ 1.00$ each; $5.6 \mathrm{ft}$., $\$ 1.50$ each; $6.8 \mathrm{ft}$., $\$ 2.00$ each.

Birch, Cut-Leaved Weeping-Grows $60 \mathrm{ft}$. Compact, graceful, with silvery-white bark. 5.6 ft., $\$ 3.00 \mathrm{each}$.

Catalpa, Bungei (Umbrella Tree)-Grows 8-10 ft. Beautiful, round, umbrella-shaped top, with dense foliage. $5.6 \mathrm{ft}$., $\$ 2.00$ each; $6.8 \mathrm{ft}$., $\$ 2.50$ each.

Catalpa, Western (Speciosa)-Grows $60 \mathrm{ft}$. Large, heart-shaped leaves. White flowers, tinged with violet and yellow. $4.5 \mathrm{ft}$., $50 \mathrm{c}$ each; $10 \mathrm{for} \$ 4.50$. $5.6 \mathrm{ft}$., $65 \mathrm{c}$ each; 10 for $\$ 6.00$. 6-8 ft., $\$ 1.00$ each; 10 for $\$ 9.00$.

Crab, Bechtel's-Grows $20 \mathrm{ft}$. One of the finest for lawn decoration. Delicate pink flowers. $2.3 \mathrm{ft}$., $\$ 1.00$ each; $3.4 \mathrm{ft}$., $\$ 1.25$ each.

Dogwood, Red Flowering (Cornus Florida Rubra)-Grows 10-20 ft. Dwarf-growing, shrub-like tree, with beautiful pink-red flowers. $2.3 \mathrm{ft} ., \$ 3.50$ each.

Dogwood, White Flowering (Cornus Florida Alba)-Grows 10-20 $\mathrm{ft}$. Same as above. White flowers. 2-3 ft., \$1.25 each.

Elm, American-Grows 60 feet. Wide-spreading branches, beautifully arched. $6.8 \mathrm{ft}$., $\$ 1.00$ each; 10 for $\$ 8.00$. $8.10 \mathrm{ft}$., $\$ 1.50$ each; 10 for $\$ 12.50$.

Flowering Cherry, Japan-Grows $20 \mathrm{ft}$. Selected strain. Rosecolored blossoms. $3.4 \mathrm{ft}$., $\$ 3.00$ each.

Horse Chestnut, White-Grows 60-80 ft. White flowers in May. $3.4 \mathrm{ft}$., $\$ 1.00$ each; $4.5 \mathrm{ft}$., $\$ 1.25$ each; $5-6 \mathrm{ft}$., $\$ 1.75$ each.

Linden, American (Basswood)-Grows 60-80 ft. Large, shining leaves, fragrant yellow flowers in July. $6.8 \mathrm{ft}$., $\$ 1.75$ each.

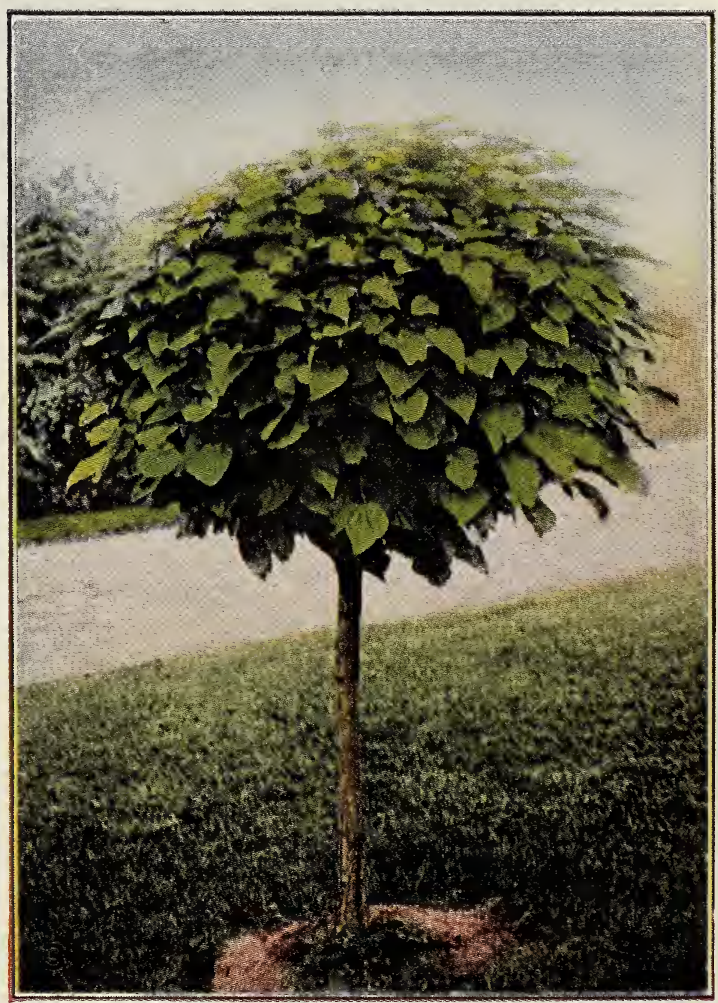

CATALPA BUNGEI (Umbrella Tree)

Ornamental Trees Cannot Be Sent Parcel Post 
Linden, European-Grows $50 \mathrm{ft}$. Leaves of deep green, silvery beneath. Cream-white flowers. $6.8 \mathrm{ft} ., \$ 1.75$ each.

Maple, Ash-Leaved (Box Elder)-Grows $60 \mathrm{ft}$. Hardy. Fastest grower. $6.8 \mathrm{ft}$., $\$ 1.00$ each; $8.10 \mathrm{ft}$., $\$ 1.25$ each.

Maple, Norway-Grows $60 \mathrm{ft}$. Most desirable shade tree for street and lawn planting. 6-8 ft., $\$ 2.25$ each; 8-10 ft., $\$ 3.00$ each; $10-12 \mathrm{ft} ., \$ 5.00$ each.

Maple, Silver (Soft Maple) - Grows $60 \mathrm{ft}$. The fastest growing of all maples. Beautiful foliage. $6-8 \mathrm{ft}$., $\$ 1.00$ each; $8-10 \mathrm{ft}$., $\$ 1.50$ each; $10.12 \mathrm{ft}$., $\$ 2.50$ each.

Maple, Sugar (Hard or Rock Maple) - Grows $80 \mathrm{ft}$. Dark green leaves, turning to scarlet in autumn. $6.8 \mathrm{ft}$., $\$ 2.50$ each.

Mulberry, Russian-Grows 20-30 ft. Beautiful foliage. Its fruit attracts birds. $4.5 \mathrm{ft} ., 50 \mathrm{c}$ each; $5.6 \mathrm{ft}$., $75 \mathrm{c}$ each; $6.8 \mathrm{ft}$., $\$ 1.00$ each.

Plane, Oriental-Grows $60 \mathrm{ft}$. A rapid-growing shade tree. It does particularly well in smoky cities. 6-8 ft., \$1.50 each.

Prunus Triloba (Double Flowered Plum) - Grows 10-12 ft. Very double, pink blossoms in spring. $2.3 \mathrm{ft}$., $\$ 1.00$ each; 3.4 $\mathrm{ft.}, \$ 1.25$ each.

Prunus Pissardi (Purple-Leaved Plum)-Grows $20 \mathrm{ft}$. Pinkish-purple leaves. $3.4 \mathrm{ft}$., $75 \mathrm{c}$ each; $4.5 \mathrm{ft} ., \$ 1.00$ each.

Poplar, Carolina (Southern Cottonwood)-Grows 60 ft. Rapid grower, wide-spreading. $6.8 \mathrm{ft}$., $50 \mathrm{c}$ each; $10 \mathrm{for} \$ 4.00$. 8.10 ft., $75 \mathrm{c}$ each; 10 for $\$ 6.00$.

Poplar, Lombardy-Grows $60 \mathrm{ft}$. Compact, pyramidal-shaped tree. Fine for windbreaks. $5.6 \mathrm{ft}$., $60 \mathrm{c}$ each; 10 for $\$ 5.00$. $6-8 \mathrm{ft}$., $85 \mathrm{c}$ each; $10 \mathrm{for} \$ 7.50$, 8.10 ft. $\$ 1.25$ each; 10 for $\$ 10.00$

Thorn, Double White (Hawthorn)-Grows $20 \mathrm{ft}$. Double, roseshaped white flowers in May. $3.4 \mathrm{ft}$., $\$ 2.25$ each.

Thorn, Paul's Scarlet (Hawthorn)-Grows $10 \mathrm{ft}$. Same as White except flowers deep crimson-scarlet. $3.4 \mathrm{ft}$., $\$ 2.25$ each.

Willow, Babylon Weeping-Grows $30-60 \mathrm{ft}$. Large, graceful tree. $5-6 \mathrm{ft} ., \$ 1.00$ each; 6-8 ft., $\$ 1.25$ each.

Willow, Golden-Grows $60 \mathrm{ft}$. A handsome tree at all seasons. Showy yellow bark. $5.6 \mathrm{ft}$., $60 \mathrm{c}$ each; $6-8 \mathrm{ft}$., $75 \mathrm{c}$ each.

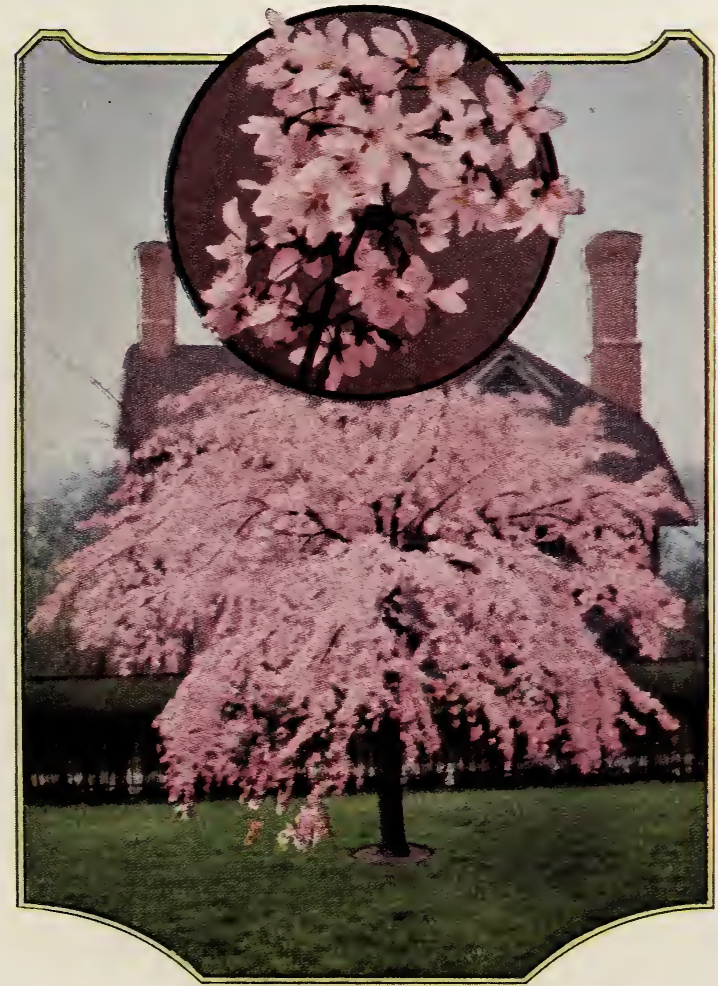

JAPANESE FLOWERING CHERRY

Do Not Overlook Our Liberal Discount for Early Orders 


\section{Standard Apple Trees}

\section{Prices of All Varieties Except McIntosh}

Size

Largest

Medium

Smaller

Age
2 yr.
2 yr.
2 yr.

Height

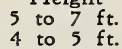

Each

3 to $4 \mathrm{ft}$

$\$ 0.80$

10
$\$ 6.00$

$\$ 6.00$
5.00

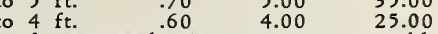

\section{SUMMER AND AUTUMN APPLES}

Gravenstein-Unexcelled for culinary use. Orange and red. Sept. Oldenburg-Yellow, splashed with red. Excellent filler. Late Aug. Red Astrachan-Yellow and crimson. Fine for cooking. July.

Sweet Bough-Large, pale yellow, sweet. Excellent quality. July. Twenty Ounce-Very large. Yellow, striped with red. Sept to Jan. Yellow Transparent-Pale yellow. Extremely hardy. Late July.

\section{WINTER APPLES}

Baldwin-Leading commercial sort. Excellent for export trade. Large, bright red, crisp and juicy. Nov. to Mar.

Cortland-An excellent new offspring of McIntosh developed by the New York State Experiment Station. An apple of the very highest quality and most pleasing flavor-fully equal if not superior to McIntosh. A little darker red and larger in size than its parent. Often called "The Improved McIntosh." Handles well and is a fine keeper. Ripens about two weeks later than McIntosh. Hangs to the tree better than any variety we know of. Bears young and a full crop every year. Cortland apples sold last year for $\$ 5.00$ per box.

Delicious-Large, conical apple. Brilliant dark red. Excellent quality. Fine for box trade. Nov. to May.

Fameuse (Snow Apple) Medium, dark red. Crisp. Nov. to Jan. Grimes Golden-Best yellow apple. Bears young. Very vigorous. Nov, to Jan.

Hubbardston-Large, mottled red and yellow. Oct. to Jan.

Jonathan-Medium size, red. Excellent quality. Nov. to Jan.

Northern Spy-A leading commercial sort. Large, bright red. Excellent keeper. Very pleasing flavor. Nov, to March.

Pumpkin Sweet-Excellent sweet apple. Very large yellow fruit. Oct. to Jan.

Rhode Island Greening-The leading cooking apple. An excellent commercial variety. Fruit large, yellowish-green. Oct. to Feb.

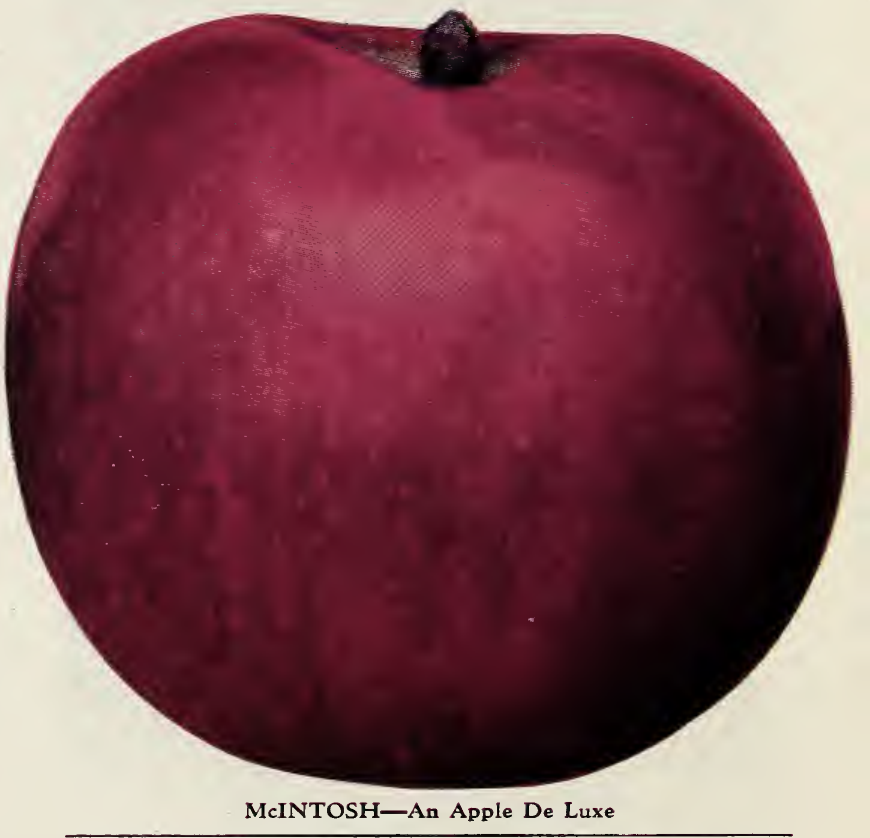

Less Than 10 Trees at Each Rate. 10 to 50 at 10 Rate 
McIntosh-Not equaled in quality and flavor by any other variety except Cortland. Its attractive, bright red color and excellent quality commands the top price in all leading markets. Tree hardy, vigorous, a good annual bearer, comes into fruiting young, yielding large crops. Oct. to Dec.

\section{Prices of McIntosh Standard Apple Trees}

\begin{tabular}{llrrrrr}
\multicolumn{1}{c}{ Size } & Age & \multicolumn{2}{c}{ Height } & Each & 10 & 100 \\
Largest & $2 \mathrm{yr}$. & 5 to $7 \mathrm{ft}$. & $\$ 0.90$ & $\$ 7.00$ & $\$ 55.00$ \\
Medium & $2 \mathrm{yr}$. & 4 to $5 \mathrm{ft}$. & .80 & 6.00 & 45.00 \\
Smaller & $2 \mathrm{yr}$. & 3 to $4 \mathrm{ft}$. & .70 & 5.00 & 35.00
\end{tabular}

BY PARCEL POST -3 to $4 \mathrm{ft}$., $50 \mathrm{c}$ each; $\$ 4.00$ per 10 , postpaid.

Rome Beauty-Medium size, yellow mottled with red. Nov. to May. Roxbury Russet-Most popular russet apple. Dec. to July.

Stayman's Winesap-Yellow, striped with dull red. Dec. to May.

Tolman Sweet-Light yellow sweet apple. Excellent for baking. Nov. to April.

Tompkins King-Large, attractive, red fruit. Tender and juicy. Oct. to Jan.

Transcendent Crab-Large, bright yellow, with red cheek. Very productive. Late Aug.

Wagener-Large, bright red. Excellent quality. A good filler. Oct. to Feb.

Wealthy-Red and yellow. Very hardy. An excellent filler. Oct. - to Jan.

Winter Banana-Attractive yellow, with bright red cheek. Distinct banana flavor. Excellent dessert apple. Nov. to Apr.

\section{Dwarf Apple Trees}

\begin{tabular}{llrrrrr}
\multicolumn{1}{c}{ Size } & Age & \multicolumn{2}{c}{ Height } & Each & \multicolumn{1}{c}{10} & 100 \\
Largest & $2 \mathrm{yr}$. & 4 to $5 \mathrm{ft}$. & $\$ 0.85$ & $\$ 7.50$ & $\$ 50.00$ \\
Medium & $2 \mathrm{yr}$. & 3 to $4 \mathrm{ft}$. & .75 & 6.50 & 40.00 \\
Smaller & $2 \mathrm{yr}$. & 2 to $3 \mathrm{ft}$. & .65 & 5.50 & 30.00
\end{tabular}

BY PARCEL POST -2 to $3 \mathrm{ft}$., $70 \mathrm{c}$ each; $\$ 6.00$ per 10 , postpaid.

\section{Varieties of Dwarf Apples We Can Furnish}

Baldwin
Cortland
Delicious

$\begin{array}{ll}\text { McIntosh } & \text { Wealthy } \\ \text { Oldenburg } & \text { Winter Banana }\end{array}$

Delicious Red Astrachan Yellow Transparent

\section{Quinces}

\begin{tabular}{lllllrr}
\multicolumn{1}{c}{ Size } & Age & \multicolumn{2}{c}{ Height } & Each & 10 & 100 \\
Largest & $2 \mathrm{yr}$. & 4 to $5 \mathrm{ft}$. & $\$ 0.85$ & $\$ 7.00$ & $\$ 50.00$ \\
Medium & $2 \mathrm{yr}$. & 3 to $4 \mathrm{ft}$. & .75 & 6.00 & 40.00
\end{tabular}

BY PARCEL POST -2 to $3 \mathrm{ft}$., $70 \mathrm{c}$ each; $\$ 6.50$ per 10 , postpaid. Orange-The best variety. Large, roundish, bright golden yellow, cooks tender and is of excellent flavor. Late Sept.

\section{Apricots}

Superb-Best flavored, most productive, hardy apricot. Medium size, light salmon color. 4 to $5 \mathrm{ft}$., $95 \mathrm{c}$ each; $\$ 8.50$ per 10 . 3 to $4 \mathrm{ft}$., $85 \mathrm{c}$ each; $\$ 7.50$ per 10 .

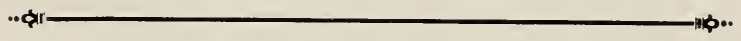

TREES COULD NOT HAVE BEEN ANY BETTER 17 Chandler St., Waverley, Mass., April 27, 1928.

I want to thank you for the quality of the goods and the manner in which my order was packed. Had my order been for ten times the amount the goods could not have been any better. Neither could they have been packed with greater care. Goods received from you previously have always been satisfactory, in fact a little above anticipation.

J. FRANK CLARK.

Fifty Trees or More at Hundred Rate 


\section{Green's Nursery Co.}

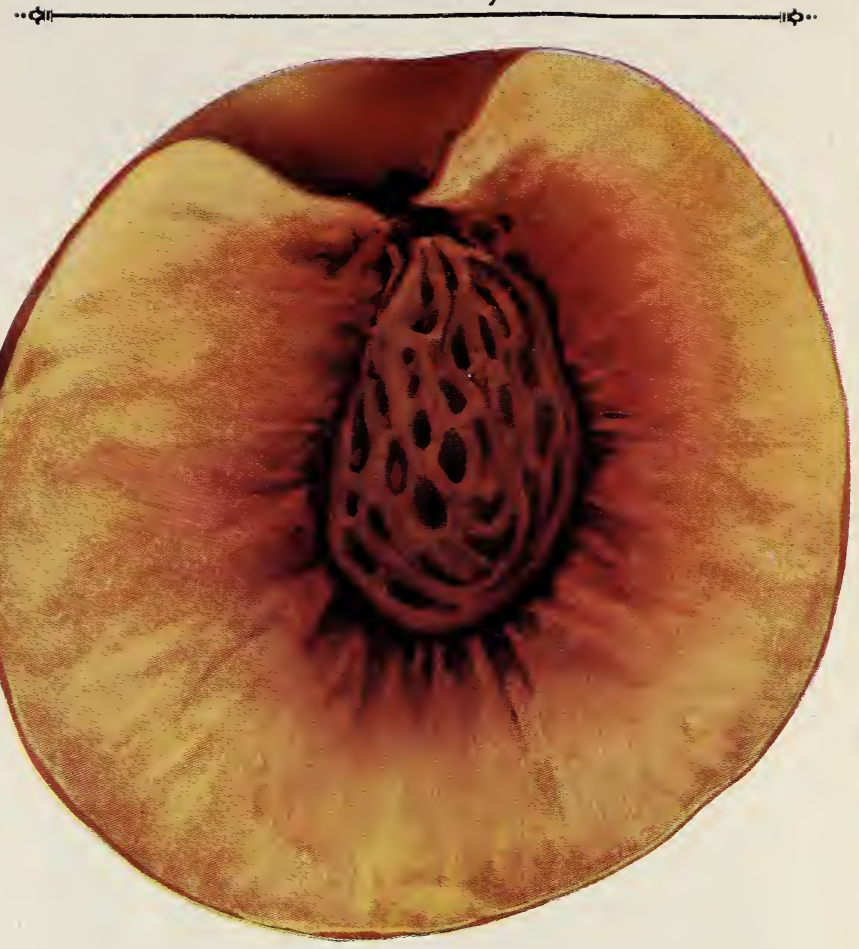

J. H. HALE PEACH-Large and Luscious

\section{PEACHES}

\begin{tabular}{llllcrr}
\multicolumn{1}{c}{ Size } & Age & \multicolumn{2}{c}{ Height } & Each & 10 & 100 \\
Largest & $1 \mathrm{yr}$. & 4 to $5 \mathrm{ft}$. & $\$ 0.75$ & $\$ 6.00$ & $\$ 37.50$ \\
Medium & $1 \mathrm{yr}$. & 3 to $4 \mathrm{ft}$. & .60 & 5.00 & 32.50 \\
Smaller & $1 \mathrm{yr}$. & 2 to $3 \mathrm{ft}$. & .50 & 4.00 & 27.50 \\
BY PARCEL & POST -2 to $3 \mathrm{ft} ., 55 \mathrm{c}$ each; $\$ 4.50$ per 10 , postpaid.
\end{tabular}

\section{ALL VARIETIES OFFERED ARE FREESTONES}

Belle of Georgia-Large, white, with crimson cheek. Aug. Carman-Large, good quality, white, with red cheek. Aug. Champion-Extra quality, white, with carmine cheek. Aug.

Elberta-The peer of all commercial peaches. Very prolific. Large, golden-yellow, with red cheek. Early Sept.

Crosby-Very hardy. Yellow, blushed with red. Sept.

Early Crawford - Highest quality. Very large, golden-yellow, blushed with dark red. Late Aug.

Greensboro-Early. Productive. White, striped with red. July.

J. H. Hale Yellow, overlaid with carmine. Very large. Late Aug. Late Crawford-Large, yellow, blushed with red. Late Sept.

Rochester-New. Best for home garden. Good commercial variety. Early. Yellow, mottled with red. Middle of Aug.

Wilma-New. Large, yellow, blushed with red. Middle of Sept.

\section{Dwarf Pear Trees}

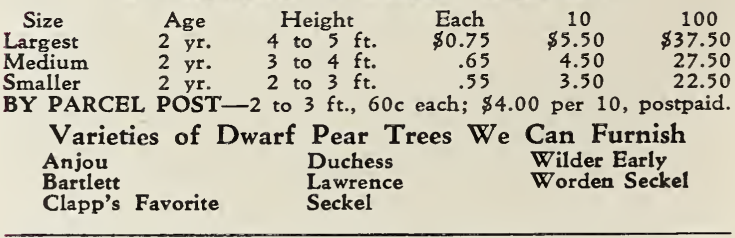

Less Than 10 Trees of a Kind at Each Rates. 10 to 50 at 10 Rates. 50 or More at 100 Rates 


\section{PEARS}

\section{Prices of Green's Standard Pear Trees,} All Varieties Except Bosc.

\begin{tabular}{lllccrr}
\multicolumn{1}{c}{ Size } & Age & Height & Each & 10 & 100 \\
Largest & $2 \mathrm{yr}$. & 5 to $7 \mathrm{ft}$. & $\$ 0.90$ & $\$ 8.00$ & $\$ 60.00$ \\
Medium & $2 \mathrm{yr}$. & 4 to $5 \mathrm{ft}$. & .80 & 7.00 & 50.00 \\
Smaller & $2 \mathrm{yr}$. & 3 to $4 \mathrm{ft}$. & .70 & 6.00 & 40.00
\end{tabular}

BY PARCEL POST -3 to $4 \mathrm{ft}$., $75 \mathrm{c}$ each; $\$ 6.50$ per 10 , postpaid.

RATES-Less than ten standard pear trees at each rates. Ten to fifty at ten rates. Fifty or more at hundred rates.

Anjou (Buerre) - Good keeper. Tasty. Oct. Keeps until Jan.

Bartlett-Large. Yellow, with red cheek. Highly flavored. Sept. Bose (Buerre)-Large. Highest quality. Best flavored. Golden russet color. Oct.

\begin{tabular}{lcrrrrr}
\multicolumn{7}{c}{ Prices of Bosc Standard Pear Trees } \\
\multicolumn{1}{c}{ Size } & Age & Height & Each & 10 & 100 \\
Largest & 2 yr. & 5 to 7 ft. & $\$ 1.10$ & $\$ 9.50$ & $\$ 75.00$ \\
Medium & $2 \mathrm{yr}$. & 4 to $5 \mathrm{ft}$. & .90 & 7.50 & 55.00 \\
Smaller & $2 \mathrm{yr}$. & 3 to $4 \mathrm{ft}$. & .80 & 6.50 & 45.00
\end{tabular}

BY PARCEL POST-3 to $4 \mathrm{ft}$., $85 \mathrm{c}$ each; $\$ 7.00$ per 10 .

Clapp's Favorite - Most productive. Large. Yellow, with russet-red cheek. Aug.

Duchess (D'Angouleme) - Excellent keeper. Bright yellow. Juicy. Oct.

Kieffer-Fair quality. Good canner. Golden yellow. Oct. to Nov.

Lawrence-Good keeper. Medium large. Golden yellow. Nov.

Seckel-Highly flavored. Fine for pickling. Russet color. Oct.

Sheldon-Extra juicy. Round. High flavor. Russet. Oct.

Wilder Early -Pale yellow. Good bearer. Ripens in early Aug.

Worden Seckel - The improved

Seckel. Larger in size. Oct.

\section{BOSC}

The Best Flavored Pear of All.

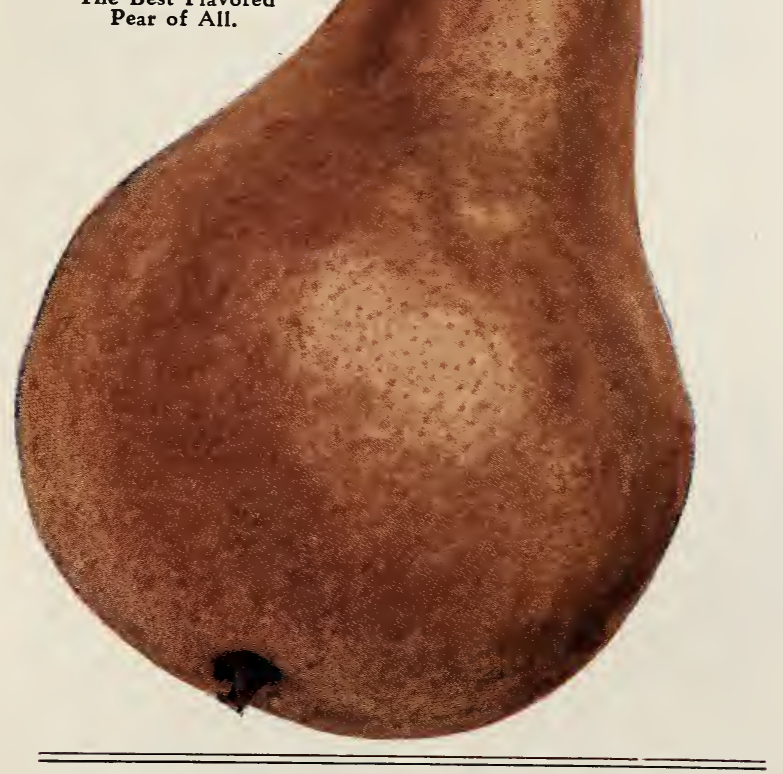

Green's Direct Method Saves You Money 


\section{Green's Nursery Co.}

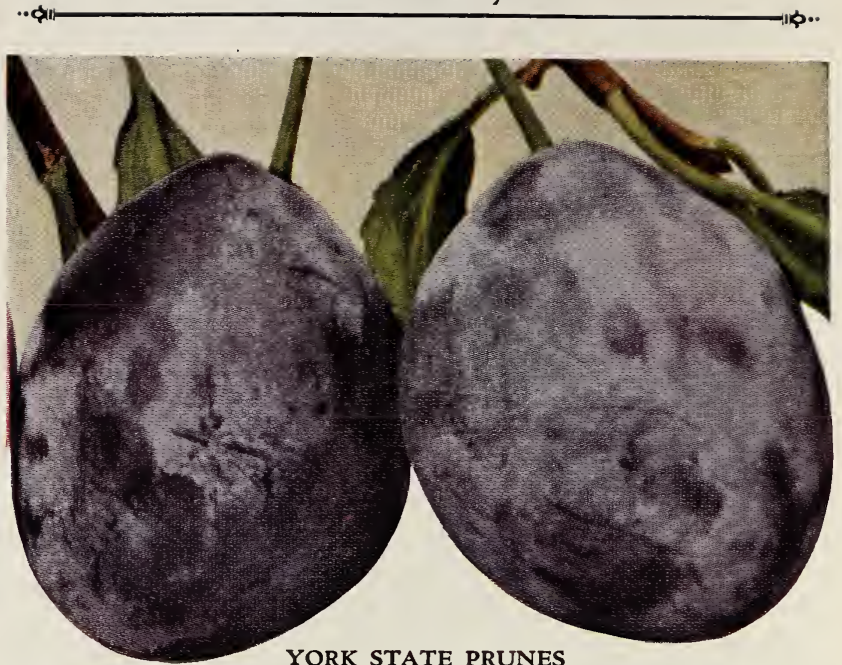

YORK STATE PRUNES

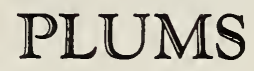

Prices of Green's Plum Trees

\begin{tabular}{llrrrrr} 
Size & Age & \multicolumn{2}{c}{ Height } & Each & 10 & 100 \\
Largest & $2 \mathrm{yr}$. & 5 to $7 \mathrm{ft}$. & $\$ 0.85$ & $\$ 6.50$ & $\$ 42.50$ \\
Medium & $2 \mathrm{yr}$. & 4 to $5 \mathrm{ft}$. & .75 & 5.50 & 32.50 \\
Smaller &. .2 & yr. & 3 to $4 \mathrm{ft}$. & .65 & 4.50 & 22.50
\end{tabular}

BY PARCEL POST -3 to $4 \mathrm{ft}$., $70 \mathrm{c}$ each; $\$ 5.00$ per 10 , postpaid. RATES-Less than ten at each rates. Ten to fifty at ten rates. Fifty or more at hundred rates.

Bradshaw-Large, dark reddish-purple. Juicy and sweet. Aug. Burbank-One of the largest and best. Reddish-purple. Late Aug. Lombard-Dark purplish-red. Very hardy. Late Aug.

Monarch-Large, purple fruit. Flesh golden-yellow. Oct.

Shropshire Damson-Small, purplish black. Excellent for preserves.

Yellow Ect.

York State Prune-The best prune. Large, purplish black. Juicy and of best quality. Freestone. Sept.

\section{CHERRIES}

\section{Prices of Green's Sweet Cherry Trees}

\begin{tabular}{|c|c|c|c|c|}
\hline $\begin{array}{l}\text { Size } \\
\text { Largest } \\
\text { Medium } \\
\text { Smaller }\end{array}$ & $\begin{array}{ll}\text { Age } \\
2 & \text { yr. } \\
2 & \text { yr. } \\
2 & \text { yr. }\end{array}$ & $\begin{array}{l}\text { Height } \\
5 \text { to } 7 \mathrm{ft} \text {. } \\
4 \text { to } 6 \mathrm{ft} \text {. } \\
3 \text { to } 5 \mathrm{ft} \text {. }\end{array}$ & $\begin{array}{r}\text { Each } \\
\$ 1.00 \\
.90 \\
.80\end{array}$ & $\begin{array}{r}10 \\
\$ 9.00 \\
8.00 \\
7.00\end{array}$ \\
\hline
\end{tabular}

BY PARCEL POST -3 to $4 \mathrm{ft}$., $85 \mathrm{c}$ each; $\$ 7.50$ per 10 , postpaid.

Black Tartarian-Large, purplish-black, heart-shaped. Middle of June.

Governor Wood-Large, yellow, tinged with crimson. High quality. June.

Napoleon-Yellow, red cheek. Flesh crisp and juicy. July.

Windsor-Large, dark red. Best late cherry. July.

\section{Prices of Green's Sour Cherry Trees}

\begin{tabular}{llllrrr}
\multicolumn{1}{c}{ Size } & Age & \multicolumn{2}{c}{ Height } & Each & 10 & 100 \\
Largest & $2 \mathrm{yr}$. & 5 to $6 \mathrm{ft}$. & $\$ 0.95$ & $\$ 7.50$ & $\$ 65.00$ \\
Medium & $2 \mathrm{yr}$. & 4 to $5 \mathrm{ft}$. & .85 & 6.50 & 55.00 \\
Smaller & $2 \mathrm{yr}$ & 3 to $4 \mathrm{ft}$. & .70 & 5.50 & 45.00
\end{tabular}

BY PARCEL POST-2 to $3 \mathrm{ft}$., $50 \mathrm{c}$ each; $\$ 4.00$ per 10 , postpaid.

Early Richmond-Best early. Dark red. Juicy and tender. June. English Morello-Best late. Very dark red. Hardy. Aug.

Montmorency-Best all around sour cherry. Dark red. Tender and

RATES-Less than ten at each rates. Ten to fifty at ten rates. Fifty or more at hundred rates. 


\section{STRAWBERRIES}

We Ship All Strawberry Plants Separately, by Parcel Post. Prices are Postpaid.

Cooper-Strong grower. Large, bright red berries, deliciously sweet. Strong plants, $\$ 1.00$ per $25 ; \$ 2.50$ per 100 , postpaid.

Corsican-Super size berries of highest quality. Vigorous growers. Early June. Strong plants, $\$ 1.10$ per $25 ; \$ 3.00$ per 100 , postpaid.

Kellogg's Premier-Extra early. Large crops. Fine quality. Strong plants, $\$ 1.00$ per $25 ; \$ 2.50$ per 100 , postpaid.

Mastodon (Everbearing) - Bears June to fall immense berries of choicest quality. Strong plants, $\$ 1.50$ per $25 ; \$ 4.50$ per 100 , postpaid.

Progressive (Everbearing) -Bears June to fall. Medium large. Delicious flavor. Strong plants, $\$ 1.25$ per $25 ; \$ 3.50$ per 100 , postpaid.

RATES-Less than 50 at 25 rates. Fifty or more at 100 rates.

\section{GOOSEBERRIES}

Chautauqua-Large, greenish yellow, fine quality, sweet. Extra size 2 yr. bushes, $40 \mathrm{c}$ each; $\$ 3.50$ per $1.0 ; \$ 27.50$ per 100 .

Downing-Commercial variety, very productive, excellent quality, pale green. Extra size 2 yr. bushes, $25 \mathrm{c}$ each; $\$ 2.00$ per 10 ; $\$ 15.00$ per 100 .

Red Jacket-Large, bright red, best quality, very prolific, hardy. Extra size 2 yr. bushes, $40 \mathrm{c}$ each; $\$ 3.50$ per $10 ; \$ 27.50$ per 100 .

RATES-Less than 10 at each rates. 10 to 50 at 10 rates. 50 or more at 100 rate.

PARCEL POST-Postage paid, for $3 \mathrm{c}$ per bush extra.

\section{BLACKBERRIES}

PRICES OF GREEN'S STRONG, 2-YEAR-OLD BUSHES.

$$
\begin{array}{lll}
10 & 100 & 1000 \\
\$ 1.00 & \$ 7.00 & \$ 45.00
\end{array}
$$

By Parcel Post, postpaid, 1c per bush extra.

RATES-Less than 50 at 10 rates. 50 to 300 at 100 rates. 300 or more at 1000 rates.

Blowers-Large, bright berries of fine quality. Good shippers. July-

Eldorado- Sweet, large, jet black berries. High quality. Good keepers. July.

Snyder-Popular, very hardy. Berries medium size, deliciously sweet.

\section{ASPARAGUS}

RIGHTFULLY CALLED THE "VEGETABLE ARISTOCRAT"

Palmetto- A very early variety, fine large stalks of excellent quality. Prices, strong 2 and 3 yr. old roots, $60 \mathrm{c}$ per $25 ; \$ 1.50$ per 100 ; $\$ 10.00$ per 1000 .

Washington-New rust proof variety. Fine flavor. Large green stalks. Prices, strong 2 and 3 yr. roots, $\$ 1.00$ per $25 ; \$ 2.00$ per $100 ; \$ 12.00$ per 1000 .

RATES-Less than 50 at 25 rates. 50 to 300 at 100 rates. 300 or more at 1000 rates.

PARCEL POST-Postage paid, for 10c per 25; 25c per 100 additional to above prices.

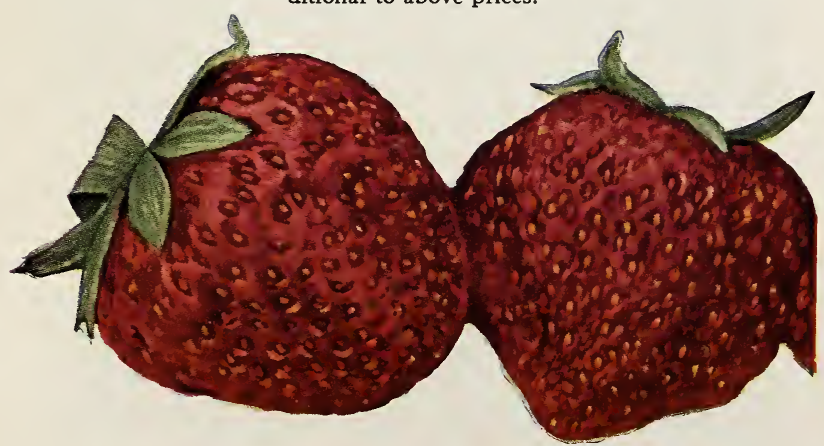

CORSICAN-C. A. Green's Favorite

Over 50 Years Experience Growing Trees and Plants 


\section{Green's Nursery Co.}

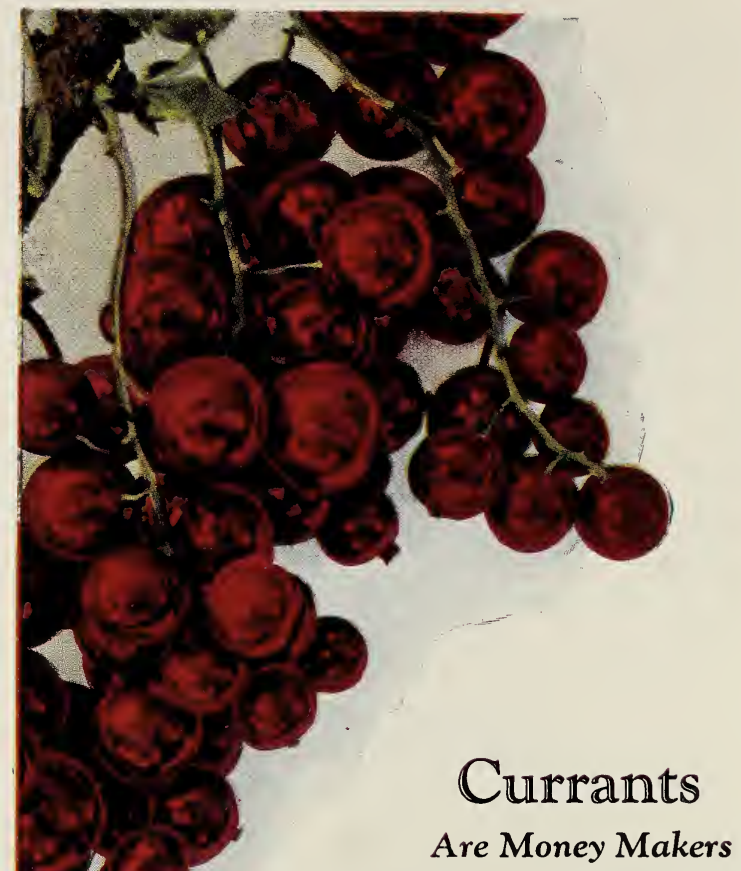

Plant Four Feet Apart Each Way.

Prices of Green's Extra Size 2 Year Bushes, Except Perfection

$\begin{array}{lccc}\text { Each } & 10 & 100 & 1000 \\ \$ 0.20 & \$ 1.50 & \$ 10.00 & \$ 65.00\end{array}$

By Parcel Post, postpaid, for $2 \mathrm{c}$ per bush extra.

RATES-Less than 10 at each rates. 10 to 50 at 10 rates. 50 to 300 at hundred rates. 300 or more at 1000 rates.

Diploma-Best red variety. Large. Productive. Sweet and juicy. Fay's Prolific-Berries above average size. Excellent flavor.

Perfection-Extra large berries and bunches. Rich, mild, sub-acid flavor. Prices $-2 \mathrm{yr}$. bushes, $40 \mathrm{c}$ each; $\$ 3.50$ per $10 ; \$ 30.00$

Red Cross-Productive. Strong grower. Unusually sweet. Fine for canning.

White Grape-Best white variety. Very prolific. Fine, large, sweet berries.

Wilder-Best for home garden. Productive. Good keeper. Bright red.

\section{SAGE}

Holt's Mammoth-Select variety. Forms dense mass of light green leaves. Prices, strong, transplanted roots, $35 \mathrm{c}$ each; $\$ 3.00$ per $10 ; \$ 20.00$ per 100 . By Parcel Post, postpaid, 2c per root extra.

\section{HORSE RADISH}

English-Every lover of horse radish should have his own supply. Prices of strong sets, $\$ 1.00$ per $25 ; \$ 3.00$ per $100 ; \$ 25.00$ per 1000. By Parcel Post, postpaid, 5c per 10 extra.

\section{RHUBARB}

Myatt's Linnaeus-Best variety. Large, tender, refined flavor. Prices, extra strong, 2 yr. roots, $25 \mathrm{c}$ each; $\$ 2.00$ per $10 ; \$ 10.00$ per 100. By Parcel Post, postpaid, for $3 \mathrm{c}$ per root extra.

You Get More for Your Money at Green's 
Rochester, N. Y.

\section{Raspberries}

EASY TO GROW, REQUIRE LITTLE CARE. PLANT 4 FEET APART IN ROWS 6 FEET APART.

Prices of All Varieties Except Plum Farmer and Syracuse

STRONG, 2-YEAR-OLD, TRANSPLANTED BUSHES

$\begin{array}{ccc}10 & 100 & 1000 \\ \$ 1.25 & \$ 8.00 & \$ 60.00\end{array}$

By Parcel Post, Postpaid, for 2c per Bush Extra.

RATES-Less than 50 at 10 rates. 50 to 300 at 100 rates. 300 or mole at 1000 rates.

Columbian (Purple)-Most profitable of all. Productive. Excellent shippers. Mid-season.

Cuthbert (Red) - Old favorite. Fine quality. Season medium late.

Herbert (Red)-Best for northern states. Good quality. Large. Mid-season.

Latham (Red) - New; of fine commercial value. Productive. Long, early season.

Plum Farmer (Black)-Best black grown. Ripens early. Brings highest prices. Prices, 2 yr. transplants: $\$ 1.00$ per $10 ; \$ 6.00$ per $100 ; \$ 50.00$ per 1000 .

Syracuse (Red)-Best for home. Largest of all. Finest quality. Early.

Strong, Two-Year-Old Transplanted Bushes, $\$ 1.50$ per $10 ; \$ 10.00$ per 100 .

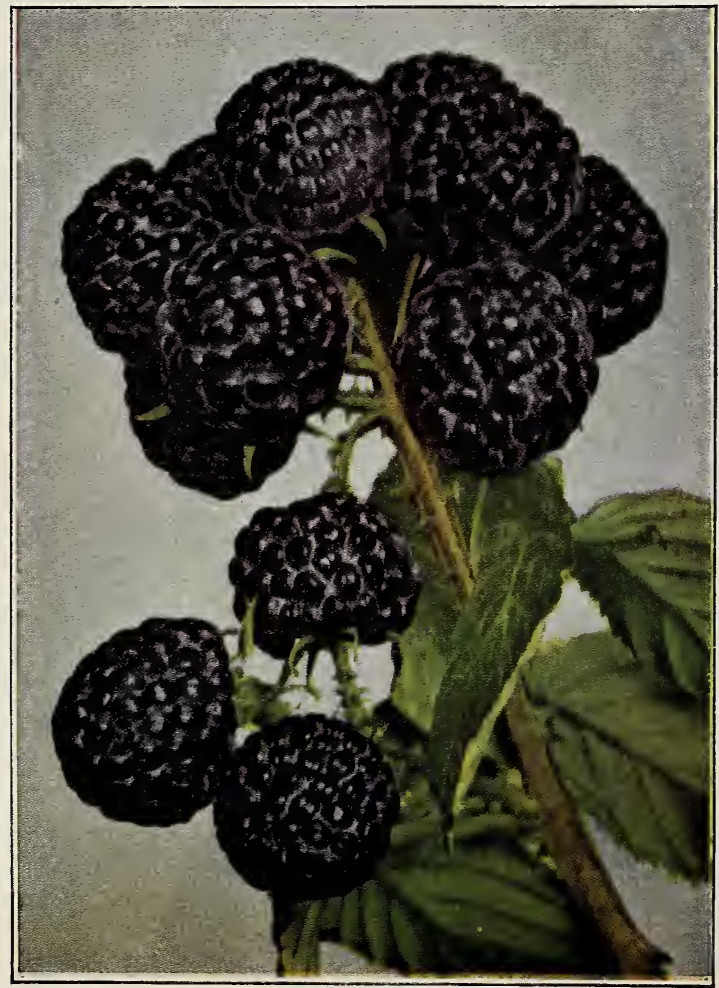

PLUM FARMER-The Best Black

Send Your Order Early-It Pays 


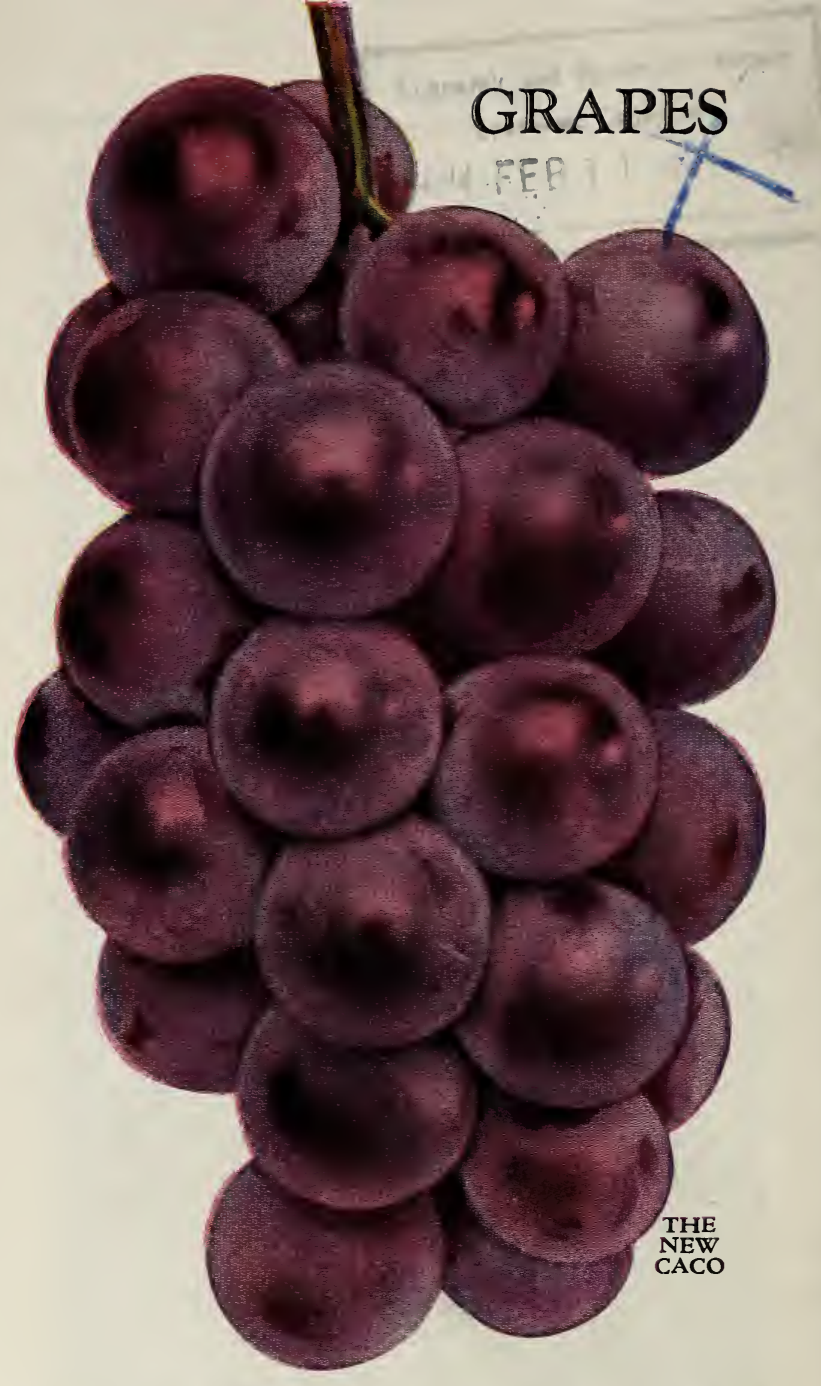

Green's Extra Size, Two-Year-Old Vines. Prices of All Varieties Except Caco, Ontario and Concord: $30 \mathrm{c}$ each; $\$ 2.50$ per $10 ; \$ 18.00$ per 100 .

BY PARCEL POST - $5 c$ per vine extra for postage and extra packing. Agawam (Red)-An excellent keeper. Large berries. Decidedly spicy flavor. Sept.

Caco (Red) - New. Super size. Deliciously sweet. Highest quality of all. Ripens early in Sept. Prices, extra size, two-year-old Caco grape vines, $60 \mathrm{c}$ each; $\$ 5.00$ per $10 ; \$ 40.00$ per 100 . By Parcel Post, $5 \mathrm{c}$ per vine extra.

Catawba (Red) - Good keeper and shipper. Very productive. High quality. Late Sept.

Concord (Black) - Leading commercial grape. Medium size. Fine flavor. High quality. Late Sept. Prices, $20 \mathrm{c}$ each; $\$ 1.50$ per $10 ; \$ 12.00$ per 100 . By Parcel Post, $5 \mathrm{c}$ per vine extra.

Delaware (Red) -Rich, delicate flavor. Highly prized for home consumption. Hardy. Medium size. Middle Sept.

Lucile (Red)-Large bunches. Extra hardy. Fair quality. Early

Sept.
Moore Early (Black)-Best early black variety. Vigorous. Hardy. Medium size. Early Sept.

Niagara (White)-Leading commercial white grape. Productive. Large bunches. Good quality. Middle Sept.

Ontario (White) - New, early white grape. Large clusters of medium size berries. Juicy. Sweet. Prices, $60 \mathrm{c}$ each; $\$ 5.00$ per 10. By Parcel Post, $5 \mathrm{c}$ per vine extra.

Worden (Black)-Seedling of Concord. Larger bunches. Better quality. Early Sept.

THE GENESEE PRESS. ROCHESTER, N.Y. 